\title{
Cambrian rocks and faunas of the Wachi La, Black Mountains, Bhutan
}

\author{
NIGEL C. HUGHES*†, PAUL M. MYROW \\ D. A. T. HARPER $\S$, O. N. BHARGAVA 9, S. K. TANGRI\|, K. S. GHALLEY\# \\ \& C.M. FANNING** \\ * Department of Earth Sciences, University of California, Riverside, CA 92521, USA \\ $\ddagger$ Department of Geology, Colorado College, Colorado Springs, CO 80903, USA \\ §Natural History Museum of Denmark, University of Copenhagen, Øster Voldgade 5-7, DK-1350, \\ Copenhagen K, Denmark \\ \103 Sector 7, Panchkula, Harayana 134109, India \\ \|Geological Survey of India, 3, Sector 33, Chandigarh 160020, India \\ \#Department of Geology and Mines, Royal Government of Bhutan, Ministry of Economic Affairs, \\ P.O. Box 173, Thimpu, Bhutan \\ ** Research School of Earth Sciences, The Australian National University, Canberra, ACT 0200, Australia
}

(Received 12 June 2009; accepted 21 July 2010; first published online 14 September 2010)

\begin{abstract}
The Pele La Group in the Wachi La section in the Black Mountains of central Bhutan represents the easternmost exposure of Cambrian strata known in the Himalaya. The group contains a succession of siliciclastic rocks with minor amounts of carbonate, the uppermost unit of which, the Quartzite Formation, bears age-diagnostic trilobite body fossils that are approximately $493 \mathrm{Ma}$ old. Trilobite species include Kaolishania granulosa, Taipaikia glabra and the new species Lingyuanaspis sangae. A billingsellid brachiopod, Billingsella cf. tonkiniana, is co-occurrent. This fauna is precisely correlated with that of a specific stratigraphic horizon within the upper part of the Kaolishania Zone, Stage 9 of the Cambrian System, Furongian Epoch of the North China block, and thus represents the youngest Cambrian sedimentary rocks yet known from the Himalaya. The faunal similarity suggests proximity between North China and the Himalayan margin at this time. This unit was deposited in a predominantly storm-influenced shelf and shoreface environment. U-Pb geochronological data from detrital zircon grains from the fossil-bearing beds of the Quartzite Formation and strata of the underlying Deshichiling Formation show grain age spectra consistent with those from Cambrian rocks of the Lesser and Tethyan Himalaya in Tibet, India and Pakistan. These data support continuity of the northern Gondwanan margin across the Himalaya. Prominent peaks of approximately $500 \mathrm{Ma}$ zircons in both the Quartzite and Deshichiling formations are consistent with the Furongian (late Cambrian) age assignment for these strata. The presence of these relatively young zircon populations implies rapid post-cooling erosion of igneous bodies and subsequent deposition which may reflect the influence of a widespread Cambro-Ordovician orogenic event evident in the western Himalaya.
\end{abstract}

Keywords: Cambrian, detrital zircon, trilobite, Himalaya, palaeogeography.

\section{Introduction}

Understanding of the pre-collisional stratigraphic and erosional history of the Himalaya is critical for reconstruction of the structural, tectonic and depositional history of the Himalayan orogeny. The Cambrian System is of special importance in this regard because of its widespread distribution along and across the Himalaya (Hughes \& Jell, 1999), and recent work provides the outline of a stratigraphic correlation for Neoproterozoic and Cambrian rocks that stretches from Pakistan to the Everest region of Nepal, and across strike onto the Indian craton (Bhargava, 1998; DiPietro \& Pogue, 2004; Hughes et al. 2005; Myrow et al. 2009, 2010). These correlations have allowed for precise age determination of strata even in the absence of diagnostic fossils (Myrow et al. 2009),

$\dagger$ †uthor for correspondence: nigel.hughes@ucr.edu and have permitted reinterpretation of the structural relationships across major Himalayan fault systems. They suggest that the entire Himalayan region was once blanketed in a thick Neoproterozoic to late middle Cambrian succession, most of which has since been eroded. In the northernmost of the Himalayan lithotectonic zones, the Tethyan Himalaya, syntectonic terrestrial and marine rocks of probable Early or Middle Ordovician age (see Torsvik et al. 2009) unconformably overlie Cambrian strata and are associated with a tectonic event known as the Kurgiakh (Srikantia, 1981) or Bhimphedian (Cawood, Johnson \& Nemchin, 2007) orogeny.

Furongian (late Cambrian) rocks, which are absent in the central and western parts of the Himalaya, are present in Bhutan (see Section 4). Rocks of this age occur sporadically across much of southeastern Asia and extensively in China. Indeed, upper Cambrian deposits have been confirmed from western Yunnan, Myanmar, 

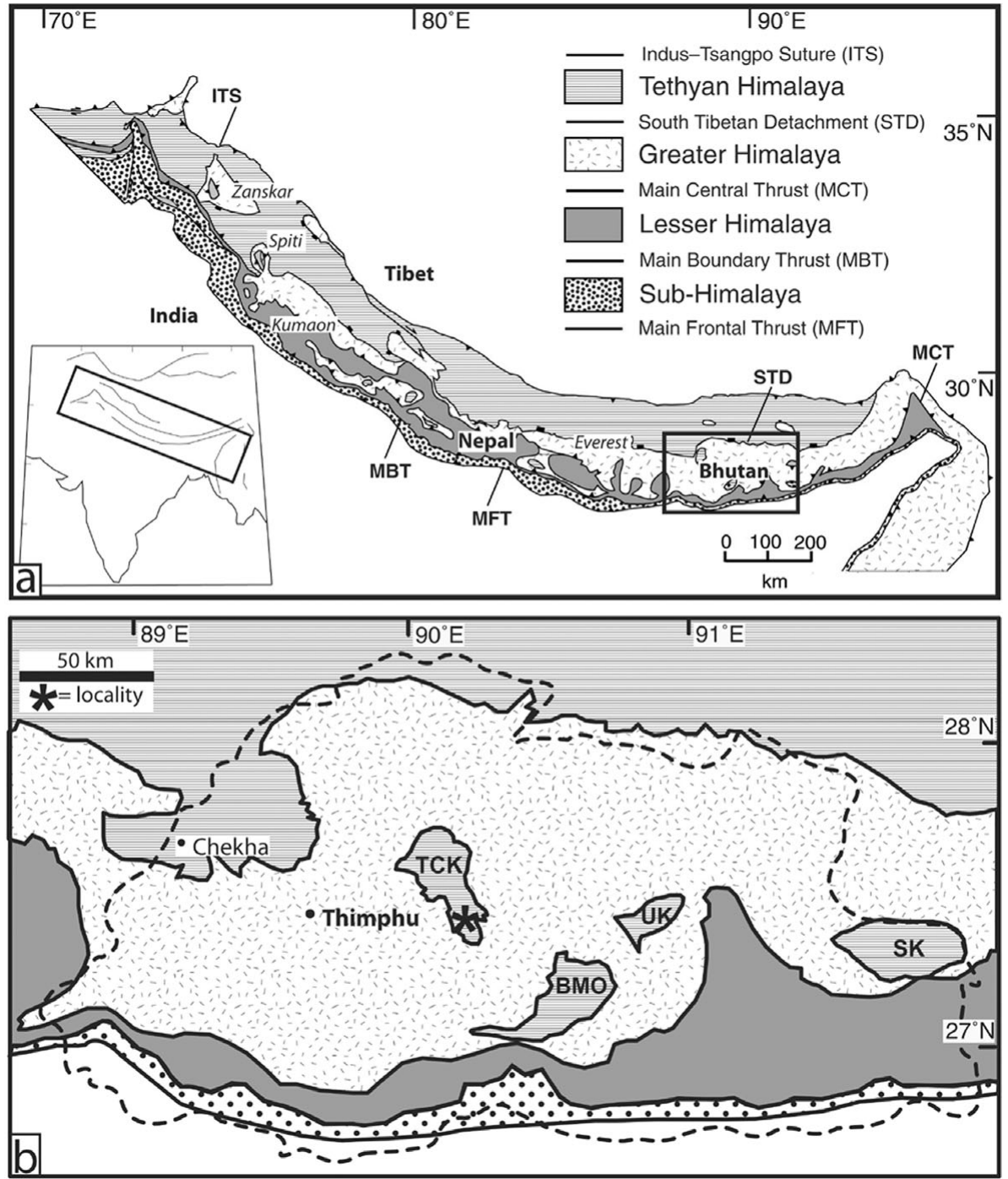

Figure 1. (a) Simplified geological map of Himalayan orogenic system and lithotectonic divisions (modified from Yin, 2006). (b) Geological map of Bhutan: TCK - Tang Chu klippe, BMO - Black Mountain outlier, UK - Ura klippe, SK - Sakteng klippe (modified from Grujic, Hollister \& Parrish, 2002).

Thailand and Vietnam (Zhang, 1988), whereas rocks of earlier Cambrian ages are poorly described or unknown from these regions. Thus, with regard to Cambrian geology, Bhutan serves as a potentially pivotal tiepoint between the Himalayan region and the rest of SE Asia, as well as with parts of China. Comparisons of lithostratigraphic and biostratigraphic aspects of the Cambrian strata of Bhutan with those to the east provide a framework for the regional tectonostratigraphic affinities of the Himalayan margin. Here we provide sedimentological, stratigraphic, palaeontological and detrital zircon geochronological data with which to assess these relationships.

\section{Geological setting and previous work}

\section{2.a. Geological context of the Wachi La succession}

Between its western and eastern syntaxes two of the three northern Himalaya lithotectonic zones contain sedimentary rocks, namely the Lesser Himalaya and
Tethyan Himalaya (Myrow et al. 2003). An intervening zone of high-grade metamorphic rock of igneous and sedimentary protolith, the Greater Himalaya, separates these zones (Fig. 1). The boundaries between these lithotectonic zones are important tectonic structures, such as the Main Central Thrust, which separates the Greater Himalaya and the Lesser Himalaya, and the South Tibetan Fault System, a top-to-the-north normal fault that separates the Greater Himalaya and Tethyan Himalaya.

Cambrian sedimentary rocks occur in both the Lesser Himalaya and the Tethyan Himalaya in the central and western sectors of the Himalaya, and as sedimentary protolith in the Greater Himalaya (Myrow et al. 2009). This distribution and the stratigraphic characteristics of these rocks suggest a passive margin during Cambrian deposition that progressively deepened to the north (Brookfield, 1993; Searle, 1996; Myrow et al. 2003; Hughes et al. 2005). In the western and central Himalaya, no Cambrian sedimentary rock younger than about $501 \mathrm{Ma}$ is known (Peng et al. 2009). 


\begin{tabular}{|c|c|c|c|c|}
\hline Nautiyal et al., 1964 & Jangpangi, 1978 & $\begin{array}{c}\text { Chaturvedi, Mishra \& } \\
\text { Mulay, } 1983 a, b\end{array}$ & \begin{tabular}{|c|} 
Tangri \& Pande, \\
1995 \\
\end{tabular} & $\begin{array}{c}\text { Grujic, Hollister \& } \\
\text { Parrish, 2002 } \\
\end{array}$ \\
\hline Tongchu Series & \begin{tabular}{ll} 
Tangchu Series \\
\hdashline \\
\hdashline
\end{tabular} & \begin{tabular}{c:c} 
Black & Black \\
Mountain & Mountain \\
Group & Group \\
& \\
\hdashline Mao-Khola & Maokhola \\
Group & Group
\end{tabular} & $\begin{array}{c}\text { Tang Chu Group } \\
\text { Pele La Group } \\
\text { Chekha } \\
\text { Formation }\end{array}$ & $\begin{array}{l}\text { Tethyan Sediments } \\
\text { Chekha } \\
\text { Formation }\end{array}$ \\
\hline
\end{tabular}

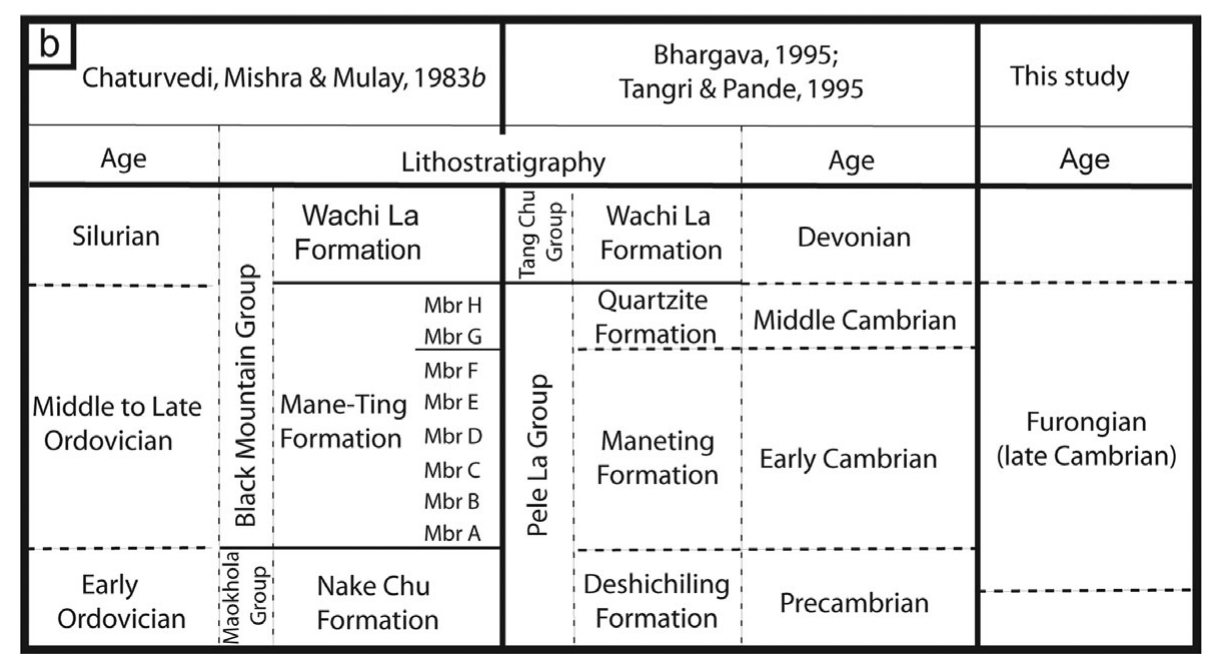

Figure 2. (a) General summary of nomenclature applied to lower Tethyan strata of the Bhutanese outliers. (b) Summary of nomenclature and chronostratigraphy of the Pele La Group, Wachi La section. Spellings are as given in the original references.

The succession in Bhutan differs in several ways. Although continuous lithotectonic belts of both Tethyan Himalayan and Lesser Himalayan strata are present in the northern and southern parts of the country, respectively, Bhutan also contains a series of outliers bearing sedimentary rocks that are situated within the Greater Himalayan lithotectonic belt (Gansser, 1983; Bhargava, 1995; Grujic, Hollister \& Parrish, 2002) (Fig. 1a), although the number and boundaries of the outliers recognized differ among authors. The Pele La Group, which contains the material described herein, belongs to a region containing Palaeozoic rocks that has been termed the Tang Chu or Pele La klippe (Fig. 1b) (Gansser, 1983; Grujic et al. 2006). Several Bhutanese outliers, including the Tang Chu, are reportedly underlain by thrust faults and are thus klippen (Grujic et al. 2006; Kellett, Grujic \& Erdman, 2009, but also see Long \& McQuarrie, 2010). Details of the relationship between the rocks in the Bhutanese outliers and other parts of the Himalaya have not been investigated to date.

We show herein that the age of the dated Cambrian part of the Pele La Group sedimentary succession is younger than any Cambrian strata known in the western and central Tethyan Himalaya, or in the Lesser Himalaya. The succession is also important in that it is the only Himalayan Cambrian rock bearing body fossils yet known east of the Gori Valley of the Kumaon region of India, over $1000 \mathrm{~km}$ to the WNW (Fig. 1). The absence of intervening fossil-bearing Cambrian rocks in the Tethyan Himalaya of Nepal and Tibet is likely to be due to metamorphism, as rocks of this depositional age are present in these regions (Brookfield, 1993; Myrow et al. 2009).

\section{2.b. The Chekha Formation and its stratigraphic relationship to low-grade sedimentary rocks in the Bhutanese outliers}

In NW Bhutan, where Chekha (N 27.667 ${ }^{\circ}$, E $089.217^{\circ}$ ) is located (Fig. 1b), a sequence of metasedimentary siliciclastic rocks with minor carbonates mapped as the Chekha Series was noted to be in fault contact with the high-grade gneisses of the Thimphu Series (Nautiyal et al. 1964). In the NW margin of this region Chekha Series rocks are mapped as in contact with Tethyan Himalayan rocks, and the Chekha Series is interpreted as the hanging wall of the South Tibetan Fault System (Chakungal et al. 2010, fig. 1a; Long \& McQuarrie, 2010, fig. 1). According to this view, the Chekha Series is a Tethyan Himalayan stratigraphic unit. The high-grade Thimphu Series is considered part of the Greater Himalaya (Gansser, 1983; Golani, 1995). Both series were subsequently re-designated as the Thimphu-Chekha Group and divided into the Thimphu Formation and the Chekha Formation (Jangpangi, 1978) (Fig. 2a).

The Tethyan Himalayan succession of Bhutan has not been studied in detail, and so the relationship between the Chekha Formation at its type section 
and the sedimentary rocks exposed within the outliers remains unclear. Nevertheless, the map of Nautiyal et al. (1964, fig. 1) shows the Chekha Series to be exposed in what has since been recognized as the area containing both the Tang Chu klippe and the Black Mountain outlier. This view has since been extended to include outcrops of the Chekha Formation in all the Bhutanese outliers and in the Tethyan Himalaya (Grujic, Hollister \& Parrish, 2002; McQuarrie et al. 2008; Chakungal et al. 2010; Long \& McQuarrie, 2010). In effect, the term 'Chekha Formation' has become the default stratigraphic name for all sedimentary rocks within the outliers unless they are distinguished by the presence of age-diagnostic fossils. The depositional age of the Chekha Formation in these various regions has yet to be constrained.

Nautiyal et al. (1964) noted that in the Tang Chu klippe, the Chekha Series was unconformably overlain by bryozoan-bearing limestones of the Tongchu Series. These fossiliferous rocks were referred to the Tethyan sequence by Gansser (1983). It has been suggested that the oldest fossiliferous rocks in any of the outliers are Devonian in age (Termier \& Gansser, 1974), and found only in the Tang Chu klippe (Fig. 2a) (e.g. Grujic, Hollister \& Parrish, 2002, p. 180).

Others have reported fossils from, and alternative stratigraphic nomenclatures for, older rocks in the Tang Chu klippe (Chaturvedi, Mishra \& Mulay, 1983a,b; Bhargava, 1995; Tangri \& Pande, 1995) (Fig. 2a, b). These schemes have included a stratigraphically restricted Chekha Formation that lies at the base of the sequence (Tangri \& Pande, 1995). The stratigraphy of the Cambrian rocks that overlie the Chekha Formation (sensu Tangri \& Pande, 1995) is discussed in the next section.

\section{2.c. Cambrian stratigraphy of the Wachi La succession}

This paper focuses on collections from the Pele La Group in the Wachi La region of the Tang Chu klippe which overlie rocks of the Chekha Formation (sensu Tangri \& Pande, 1995) (Fig. 1b). Initial attempts at chronostratigraphy of these rocks were conducted by Chaturvedi, Mishra \& Mulay $(1983 a, b)$ and revised by Bhargava (1995) and Tangri \& Pande (1995) (Fig. 2b). We accept Bhargava's (1995) argument that Chaturvedi, Mishra \& Mulay's $(1983 a, b)$ stratigraphic units were too poorly defined to be acceptable without extensive revision, and we therefore employ the revised scheme of Tangri \& Pande (1995), which is based on described type sections (Fig. 2). The basal unit of the Pele La Group is reportedly the Singhi Formation, which consists of rhyolitic/dactic volcanic flows. This is overlain by the quartz sandstone of the Deshichiling Formation, followed by dark shales of the Maneting Formation. The latter is succeeded by the fossiliferous fine-grained siliciclastic Quartzite Formation, which also bears minor beds of white recrystallized limestone. The overlying Wachi La Formation marks the base of the subsequent Tang Chu Group (Tangri \& Pande,
1995). The interval from the upper part of the Deshichiling Formation to above the recrystallized carbonate at the base of the Wachi La Formation is exposed in the Wachi La section and is the subject of this report. Stratigraphic heights mentioned below are in metres above the base of the Maneting Formation.

\section{Sedimentology}

\section{3.a. Description}

The Deshichiling Formation consists primarily of white vitreous and grey carbonate-cemented quartz-rich fine sandstone (Fig. 3). Beds are 5-30 cm thick and make up bed sets up to $70 \mathrm{~cm}$ thick that are separated by thin shale drapes. There are a few widely spaced, highly cleaved shale beds up to $40 \mathrm{~cm}$ thick, but most shale consists of millimetre-thick laminae. Simple bedding-parallel burrows are abundant and exist on most bedding planes. Most of the quartzite is massive, although some weathering surfaces show trough crossbed sets up to $95 \mathrm{~cm}$ thick. Additional sedimentary structures include sporadic shale intraclasts, polygonal desiccation cracks, and small symmetrical ripple marks, which confirm that the section is right-wayup.

The Maneting Formation is poorly exposed along the ridge leading to the Wachi La pass. The lower, poorly exposed part of the formation is approximately $60 \mathrm{~m}$ thick and consists of dark shale mostly exposed in float. The remainder of the formation was measured from the first exposures of interbedded shale and sandstone. The lower part consists of dark grey shale with $\tan$ weathering, very fine and fine sandstone beds (Fig. 4a). The sandstone beds average $3 \mathrm{~cm}$ in thickness and a small percentage of beds are greater than $10 \mathrm{~cm}$ thick. These beds have slightly irregular bases and contain abundant parallel lamination and small-scale hummocky cross-stratification. A single bed in float consists of $43 \mathrm{~cm}$ of trough cross-bedded fine sandstone.

The Quartzite Formation begins at $147.95 \mathrm{~m}$, at the base of a $68 \mathrm{~cm}$ thick unit with three amalgamated hummocky cross-stratified beds. The lower part of the member, from $147.95 \mathrm{~m}$ to $201.3 \mathrm{~m}$, consists primarily of variably exposed thin to medium beds $(5-15 \mathrm{~cm}$ thick) of grey, fine sandstone and minor $(<20 \%$ of thickness) shale. Sandstone beds are massive, parallel laminated and hummocky cross-stratified. From $201.3 \mathrm{~m}$ to $263.7 \mathrm{~m}$ the member consists of very poorly exposed, amalgamated, fine sandstone with large-scale hummocky cross-stratification throughout.

The interval from $263.7 \mathrm{~m}$ to $273.44 \mathrm{~m}$ in the formation consists of stacked, very thin- to thin-bedded (1-7 cm thick), grey, fine sandstone with abundant red-weathering siderite spots (weathered carbonate cement). This is interbedded with minor amounts $(<10 \%)$ of green-grey bioturbated shale with thin laminae of very fine sandstone. The laminated sandstone 


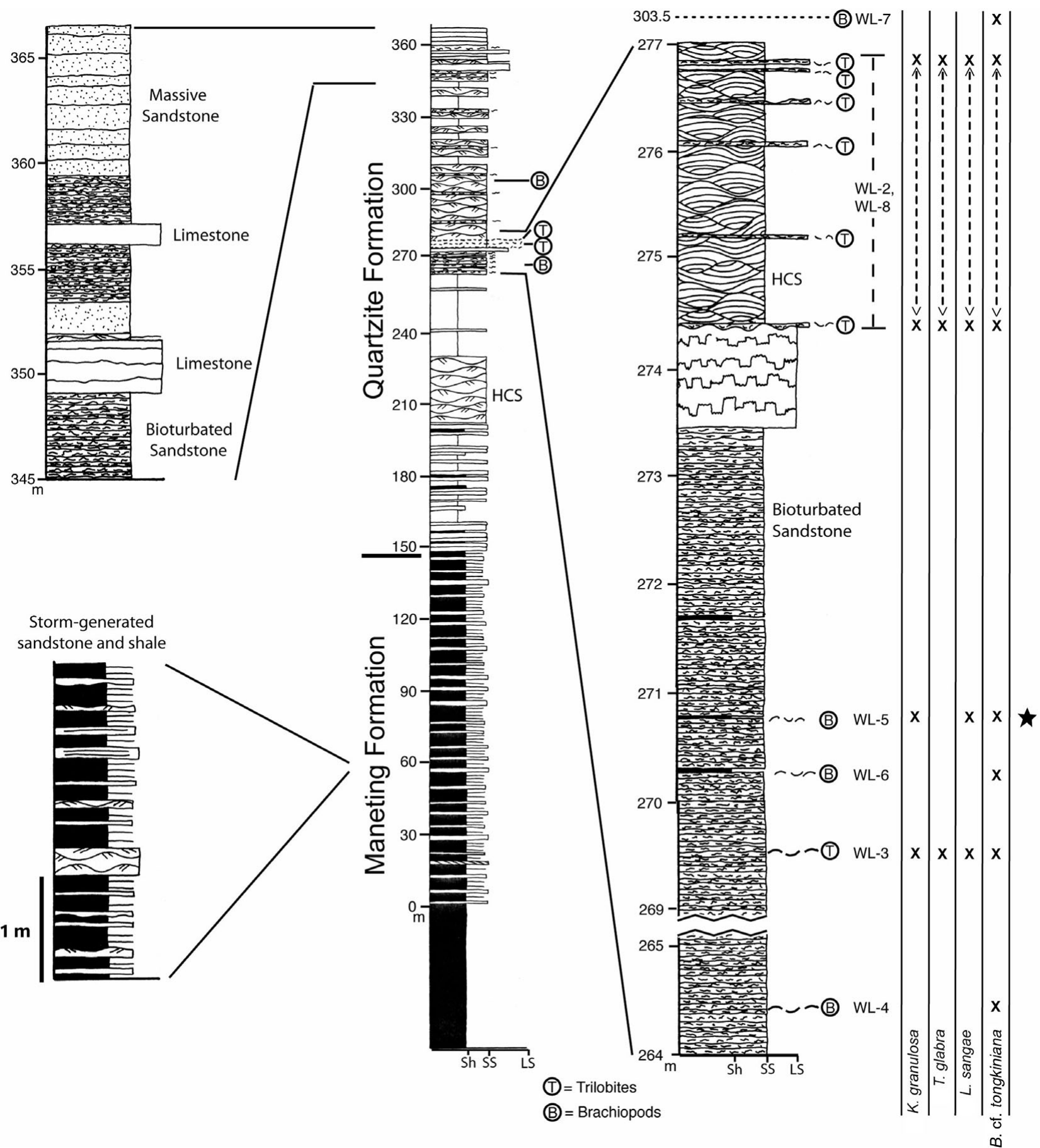

Figure 3. Stratigraphic section for the Maneting and Quartzite formations measured along the Wachi La ridge. Fossiliferous horizons are indicated by $\mathrm{T}$ (trilobites) and B (brachiopods). Representatives of both phyla were found in each horizon, but taxon abundance varied with the dominant form in each bed indicated by $\mathrm{T}$ or $\mathrm{B}$. The solid star indicates the stratigraphic position of the detrital zircon sample analysed from the Quartzite Formation. The Deshichiling Formation sample was collected below the base of this section.

contains abundant rhynchonelliform brachiopods and some trilobite fossils. Nearly all bedding planes exhibit abundant trace fossils.

A prominent $96 \mathrm{~cm}$ thick bed of white-weathering limestone exists at $273.44 \mathrm{~m}$ (Fig. 4c). This bed consists of extremely pure, homogeneous, recrystallized limestone with abundant stylolites spaced $1-5 \mathrm{~cm}$ apart. Directly above this limestone bed are thick amalgamated beds showing large-scale hummocky cross-stratification (Fig. 4b). The lower two metres of these strata contain very thin $(1-4 \mathrm{~cm}$ thick) brachiopod and trilobite coquinites (Fig. 4b, d). A $5 \mathrm{~cm}$ thick intraclast conglomerate with abundant trilobite fossils sits within a shallow scour directly on top of the limestone bed (Fig. 4e). The thick amalgamated hummocky cross-stratified deposits are interbedded with units up to $60 \mathrm{~cm}$ thick of $1-3 \mathrm{~cm}$ thick, burrowed, fine sandstone beds similar in character to those below the prominent limestone bed at $273.44 \mathrm{~m}$. This facies becomes more abundant up-section to $349.05 \mathrm{~m}$. 

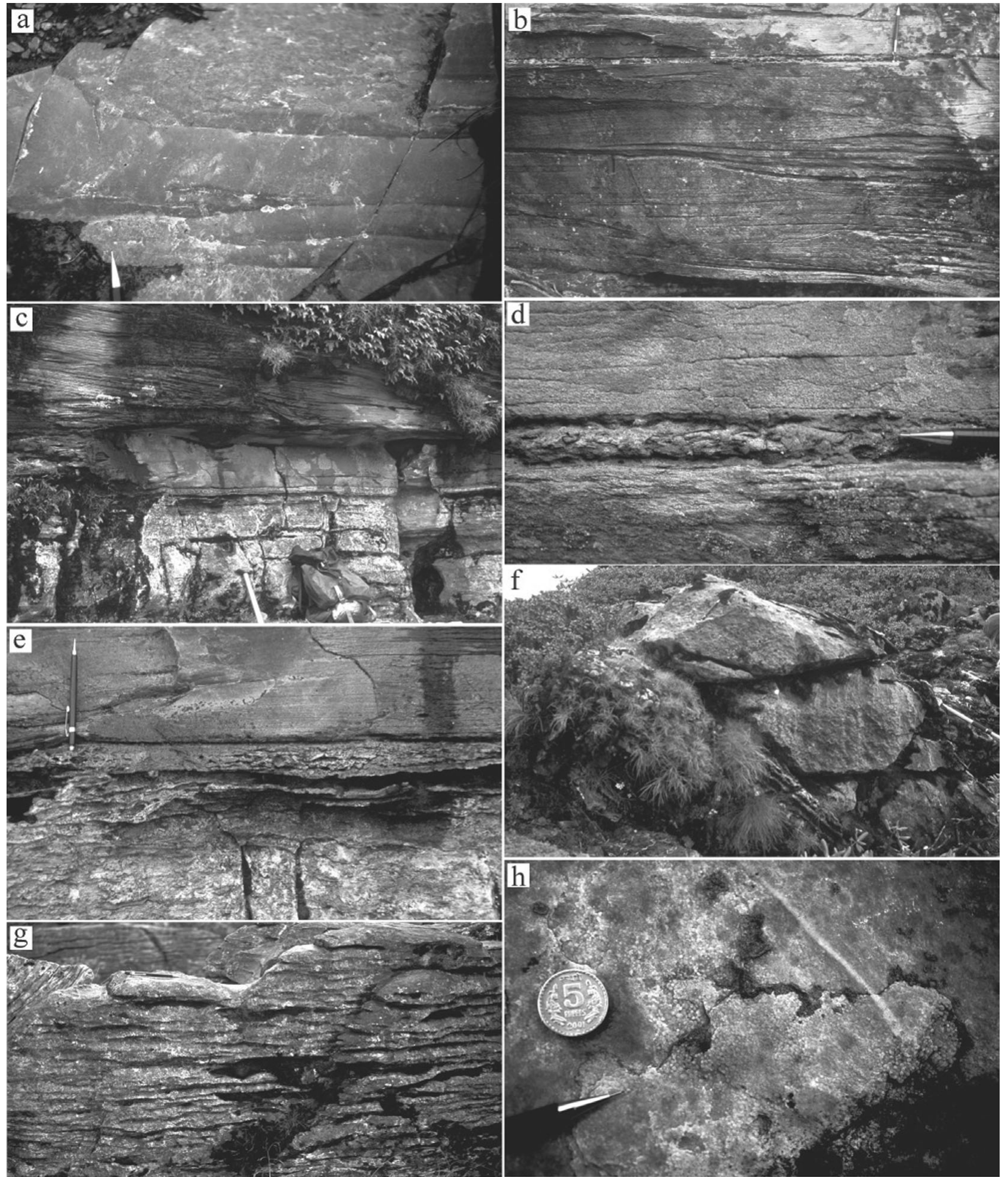

Figure 4. (a) Interbedded graded sandstone and shale from $50 \mathrm{~m}$ level in the Maneting Formation, tip of pencil $2 \mathrm{~cm}$ long. (b) Welldeveloped hummocky cross-stratification at $\sim 275 \mathrm{~m}$ level in the Quartzite Formation. Note thin trilobite hash bed at base of pencil which is $14 \mathrm{~cm}$ long (see d). (c) Thick $(96 \mathrm{~cm}$ ) white weathering recrystallized limestone bed at $273.44 \mathrm{~m}$, and overlying amalgamated hummocky cross-stratified sandstone; hammer about $34 \mathrm{~cm}$ long. (d) Two centimetre thick trilobite hash layer within amalgamated hummocky cross-stratified sandstone at $275.2 \mathrm{~m}$; tip of pencil $2 \mathrm{~cm}$ long. (e) Thin bed of flat-pebble conglomerate at $274.4 \mathrm{~m}$ that rests directly on the white limestone bed in (c); pencil $14 \mathrm{~cm}$ long. (f) Bed of blue-grey weathering limestone, $87 \mathrm{~cm}$ thick, at $356.2 \mathrm{~m}$; pencil $14 \mathrm{~cm}$ long. (g) White limestone above top of Quartzite Formation; pencil $14 \mathrm{~cm}$ long. (h) Coral-bearing surface at the top of a limestone bed above the Quartzite Formation, in the Wachi La Formation; tip of pencil $2 \mathrm{~cm}$ long; Indian five rupee coin $2.3 \mathrm{~cm}$ in diameter.

A second limestone bed exists at $349.05 \mathrm{~m}$ and consists of $2.55 \mathrm{~m}$ of tan to grey weathering, massive, mottled limestone. Up to $18 \mathrm{~cm}$ of brown weathering hummocky cross-stratified fine sandstone and white limestone are interbedded on a cm scale directly above the thick limestone bed. The white limestone beds are 


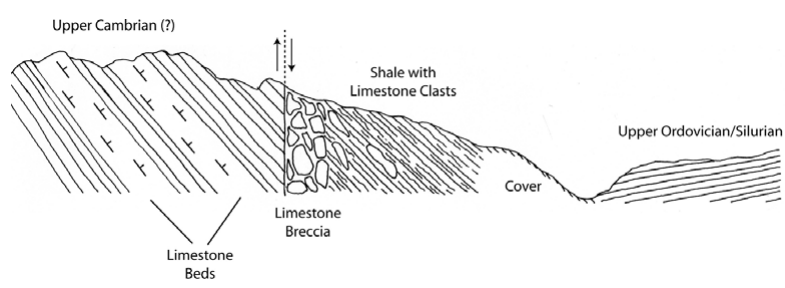

Figure 5. Sketch of the inferred geology of the upper part of the Wachi La section (above about $340 \mathrm{~m}$; see Fig. 3) showing the top of the measured section, a fault with associated fault breccia, and overlying apparently Ordovician carbonate strata with different strike and dip. The fault itself is poorly exposed. The sketch is approximately orientated east-west, with east on the right.

up to $3 \mathrm{~cm}$ thick. This is overlain by brown, sideritemottled, very thin- to thin-bedded $(1-7 \mathrm{~cm})$, burrowed fine sandstone, the lower $1.7 \mathrm{~m}$ of which contains varying minor amounts of carbonate. At $356.2 \mathrm{~m}$ is a $3.27 \mathrm{~m}$ thick white, blue-grey weathering limestone bed (Fig. 4f). The lower $87 \mathrm{~cm}$ has biohermal mounds with what may be an encrusting stromatoporoid. The rest of the section, up to $366.57 \mathrm{~m}$ consists of burrowed, thin-bedded fine sandstone.

The top of the section is defined by a prominent fault that is followed by a series of deformed shale and minor limestone beds and then a covered zone (Fig. 5). Beyond this covered zone are hundreds of metres of reefal limestone (Fig. 4g) deposits with well-preserved corals (Fig. 4h). Time limitations did not allow for a careful study of the younger limestone deposits. The nature of these deposits (colour, texture) is very similar to the thick limestone units at the top of the Quartzite Formation described above.

\section{3.b. Interpretation}

Although internal sedimentary structures are not abundant in the Deshichiling Formation, the suite of preserved sedimentary and biogenic structures is consistent with deposition within high-energy shallow marine environments. Symmetrical wave ripples with small wavelengths and desiccation cracks indicate very shallow depths, and the latter episodic subaerial exposure. The paucity of shale indicates that most deposition was above fair weather wave base, that is, metres to a few tens of metres water depth (Komar, 1976).

The lower part of the Maneting Formation, from the base of the shale member to $263.7 \mathrm{~m}$ in the measured section, is a large-scale coarsening-up succession. The dominance of parallel lamination and hummocky cross-stratification indicates that the shoreline was subjected to powerful storm events (Dott \& Bourgeois, 1982; Brenchley, 1985; Myrow \& Southard, 1996). The upward-coarsening stratigraphic trend from shale to interbedded sandstone and shale to amalgamated sandstone reflects shoaling. The facies trends and the thickness of the succession are typical of prograding storm-dominated shoreline deposits (Walker, 1984;
Myrow et al. 2006b). The loss of shale and transition into amalgamated hummocky cross-stratified beds records shallowing into a shoreface environment (Hamblin \& Walker, 1979; Walker, 1984).

The transition into the first occurrence of the burrowed, thin-bedded sandstone facies is difficult to interpret. The presence of marine fauna and abundant trace fossils indicates deposition in a marine environment. The presence of a small number of thin shale beds within this sandstone-rich facies suggests deposition in the lower shoreface transition zone (Midtgaard, 1996). This environment is also consistent with the abundance of burrows (Pemberton \& MacEachern, 1995). A shift to a lower shoreface setting would reflect a minor transgression relative to amalgamated, thicker-bedded hummocky cross-stratification. The sudden introduction of abundant burrows and the thinner bedding may reflect a decrease in sedimentation rate and/or intensity of storms, both of which may have accompanied relative sea level rise. The sharp transition into pure limestone certainly reflects a dramatic decrease in the influx of siliciclastic sediment. Unfortunately, the processes of deposition for any of the limestone beds are difficult to interpret because of the near total lack of preservation of physical and biogenic features, with the exception of small bioherms at $356.2 \mathrm{~m}$. The rapid transition into amalgamated hummocky crossstratified beds above the first limestone bed is a rather unusual facies transition that indicates a shift back to a storm-dominated shoreface environment. The very thin to thin beds of trilobite and brachiopod coquinas above the limestone bed at $263.7 \mathrm{~m}$ represent thin fossil lags produced by fair-weather waves or storm waves (Brenner \& Davies, 1973; Kidwell, 1991), and may represent concentration along minor transgressive surfaces of erosion or ravinement surfaces (Myrow, 1998).

The thicker limestone beds at the top of the section are interbedded with the burrowed, thin-bedded sandstone facies. The prominent mound shapes and the presence of reef-building marine fossils indicate that these are boundstone deposits. Once again, the shift to relatively pure carbonate deposits reflects a sharp decrease in siliciclastic deposition. As with the bed at $263.7 \mathrm{~m}$, the change from shoreface sandstone to pure limestone is an unusual facies transition. Limestone beds of older Cambrian age exposed along strike in the Spiti Valley of northern India occur at the top of upward-coarsening and -shoaling deltaic cycles as a result of the sudden reduction of sediment input during fluvial avulsion events (Myrow et al. $2006 a, b)$. Sandstone dominated shoreface deposits are almost invariably associated with shaly nearshore deposits (that is, below fair-weather wave base). Thus, the sharp upper and lower stratigraphic transitions with sandstone of possible lower shoreface origin suggests that the carbonate formed and disappeared as a facies, instead of existing long-term as a facies belt that migrated as a result of changes in relative sea level. 


\section{Systematic palaeontology}

We describe a new trilobite and rhynchonelliform brachiopod fauna collected from horizons within a 40 metre stratigraphic interval within the Quartzite Formation along the Wachi La ridge (Fig. 3) in September 2002. The fossils described herein were all collected from red weathering fine-grained sandstone. Each collection was distinguished by the collection number WL-no., the number corresponding to the section height in metres, Global Positioning System coordinates and approximate altitude: WL-2, at $274.40-276.05 \mathrm{~m}$, $\mathrm{N} 27^{\circ} 24.100^{\prime}$, E $090^{\circ} 17.575^{\prime}, 4133 \mathrm{~m}$ altitude; WL-3, at $269.54 \mathrm{~m}, \mathrm{~N} 27^{\circ} 24.090^{\prime}$, E $090^{\circ} 17.617^{\prime}, 4136 \mathrm{~m}$ altitude; $\mathrm{WL}-5$, at $270.75 \mathrm{~m}, \mathrm{~N} 27^{\circ} 24.153^{\prime}$, E $090^{\circ} 17.525^{\prime}, 4132 \mathrm{~m}$ altitude; and WL-8, at 274.40-276.05 m, N 27'24.035', E $090^{\circ} 17.593^{\prime}, 4111 \mathrm{~m}$ altitude. Chaturvedi, Mishra \& Mulay (1983a,b, fig. 1 in both publications) provided a basic geological map for the region. The trilobite taxonomy is by Ryan McKenzie and Nigel Hughes and the new taxon should be attributed to those authors. The brachiopod taxonomy is by David Harper and Ryan McKenzie. Specimens are housed in the type collection of the Royal Bhutan Department of Geology and Mines/Geological Survey of Bhutan (GSB).

\author{
Phylum ARTHROPODA \\ Class TRILOBITA \\ Order CORYNEXOCHIDA Kobayashi, 1935 \\ Suborder LEIOSTEGIINA Fortey, 1997 \\ Superfamily LEIOSTEGIOIDEA Bradley, 1925 \\ Family KAOLISHANIDAE Kobayashi, 1935
}

This family of leiostegiinid trilobites bears a single pair of prominent pygidial spines associated with the posterior band of the anteriormost pleural segment of the holaspid pygidium (Kobayashi, 1956, p. 12).

\section{Genus Kaolishania Sun, 1924}

Type species. Kaolishania pustulosa Sun, 1924 (p. 52, pl. 3, fig. 8a-h); from the Kaolishania Zone, Changshan Formation, Haolishan, Taian, Shandong province, China.

Species assigned. Kaolishania granulosa Kobayashi, 1933 (p. 104, pl. 11, figs 15, 16) from Kaolishania Zone, Paichiashan, Liaoning Province, China; Kaolishania yunnanensis Sun \& Xiang, 1979 (p. 7, pl. 1, figs 1, 2) from the upper Cambrian Liushui Formation, Lijiasi, Baoshan, Yunnan; Parakaolishania brevica Sun \& Xiang, 1979, (p. 8, pl. 1, figs 4-9) from the upper Cambrian Liushui Formation, Huajiaosi, Pupiao, Baoshan, Yunnan. Other species currently assigned to the genus are discussed below.

Diagnosis. Trapezoidal cranidium of high relief with pustulose ornament. Glabella trapezoidal with four pairs of lateral furrows, terminating in firmly incised anterior border furrow behind long (sag.), upturned anterior border. Fixigenae broad (tr.). Librigena with long (exsag.) genal spines diverging abaxially toward posterior. Librigenal lateral border furrow not confluent with posterior border furrow. Pygidium semielliptical with five or more axial rings with prominent relief, firmly incised pleural furrows, and a pair of large macropleural spines associated with the posterior band of the anteriormost pleurae.

\section{Kaolishania granulosa Kobayashi, 1933}

Figures $6 \mathrm{a}-\mathrm{j}, 7 \mathrm{a}-\mathrm{h}, 12 \mathrm{a}$

1933 Kaolishania? granulosa Kobayashi, pp. 103-5, pl. 11, figs 19, 20.

1935 Kaolishania granulata Kobayashi, pp. 175-7, pl. 8, figs 9-11; pl. 9, figs 14, 15 (nomen dubium).
1935 Kaolishania obsolata Kobayashi, pp. 177-8, pl. 9, fig. 16.

1937 Paramansuyella granulosa Endo in Endo \& Resser, p. 359, pl. 70, figs 1-9.

1956 Kaolishania granulosa Kobayashi; Kobayashi, p. 13.

1960 Kaolishania granulosa Kobayashi; Kobayashi, pp. 355-6; pl. 20, figs 8-12, pl. 21, fig. 14.

1960 Kaolishania? latiura Kobayashi, p. 356, pl. 21, fig. 19.

1965 Kaolishania granulosa Kobayashi; Lu et al., p. 422, pl. 81, figs 5, 6 .

1980 Kaolishania granulosa Kobayashi; Nan, p. 506, pl. 207, figs 2-5.

$1983 a$ ?Prosopiscus sp. or ?Annamitella sp.; Chaturvedi, Misra \& Mulay, p. 236, pl. 2, figs 1, 3, non fig. 2.

1983 ? Prosopiscus; Chaturvedi, Misra \& Mulay, p. 236, pl. 2, figs 1, 3, non fig. 2 .

1994 Kaolishania granulosa Kobayashi; Qian, p. 119.

1995 Trilobite remains; Tangri \& Pande, p. 134, figs 3.10.37-40.

1995 Kaolishaniids/pagodiids; Bhargava, p. 187, figs 5.2.9, 5.2.11.

2002 Prochuangia; Hughes, Peng \& Luo, p. 714 (discusses figured material of Bhargava, and Tangri \& Pande).

2005 Kaolishania granulosa Kobayashi; Duan et al., p. 27.

Type material. Holotype fragmentary cranidium, Kobayashi (1933, pl. 11, figs 19, 20), Kaolishania Zone, Paichiashan, Liaoning Province, China.

Bhutanese material. Twelve cranidia from WL-2 (GSB46, GSB47), WL-3 (GSB45) and WL-8 (GSB12, GSB13, GSB14, GSB15, GSB16, GSB17, GSB18, GSB48, GSB49); four librigenae from WL-2 (GSB19, GSB51), WL-3 (GSB20) and WL-8 (GSB50); and fourteen pygidia from WL-2 (GSB23, GSB52, GSB53, GSB54, GSB58, GSB59), WL-3 (GSB21) and WL-8 (GSB22, GSB24, GSB25, GSB26, GSB55, GSB56, GSB57) from the Quartzite Formation, Wachi La section, Black Mountains, Bhutan.

Diagnosis. Kaolishania with pygidium semi-elliptical bearing five well-defined axial rings and terminal piece, pleural furrows firmly impressed with four pleural ribs and a pair of long (exsag.), posteriorly divergent marginal spines.

Description. Pustulose cranidium with length (sag.) approximately $50 \%$ of width (tr.) at posterior border. Glabellar length (sag., including occipital ring) about $80 \%$ of total cranidial length (sag.), tapering gently anteriorly, with rounded anterolateral corners and transverse anterior margin. Axial furrow firmly incised, shallowing slightly anteriorly, confluent with four pairs of lateral glabellar furrows. SO long (sag.), transverse, deeply incised abaxially, shallower medially, confluent with axial furrow. S1 deeply incised abaxially, obsolete in medial glabellar third, oblique rearward at approximately $45^{\circ}$ angle to sagittal axis, bifurcate in adaxial most portion in some specimens; S2 transverse or oblique posteriorly at low angle (tr.), shorter (exsag.) than S1, crossing one third of glabellar width; S3 faint, transverse, crossing one quarter of glabellar width. L1 subtriangular abaxially. LO width (tr.) of similar width to posterior of L1 (tr.), bearing tiny medial node. Anterior margin of LO bowed slightly forward medially. Preglabellar furrow long (sag.). Anterior border about $15 \%$ of cranidial length (sag.), convex dorsally, with steep posterior margin, 

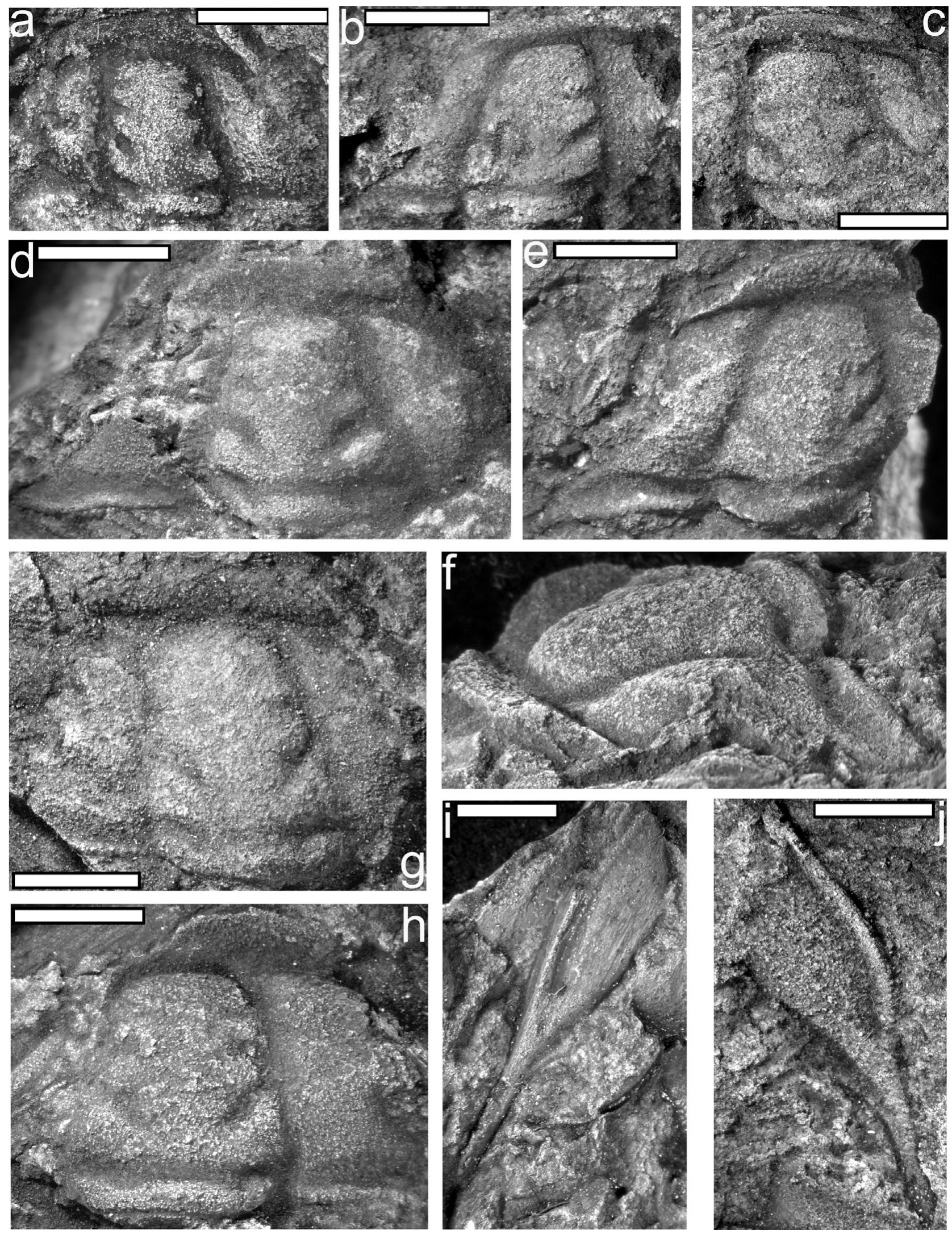

Figure 6. Cephalic sclerites of Kaolishania granulosa Kobayashi from the Quartzite Formation, Wachi La section, Bhutan. All specimens are coated with ammonium chloride sublimate prior to digital photography, specimens are internal surfaces of moulds unless otherwise stated. White scale bar is $5 \mathrm{~mm}$ long. (a) GSB12, partial cranidium. (b) GSB13, partial cranidium. (c) GSB14, partial cranidium. (d) GSB15, partial cranidium. (e, f) GSB16, partial cranidium; (e) dorsal view; (f) oblique view. (g) GSB17, partial cranidium. (h) GSB18, partial cranidium. (i) GSB19, librigena. (j) GSB20, librigena. 

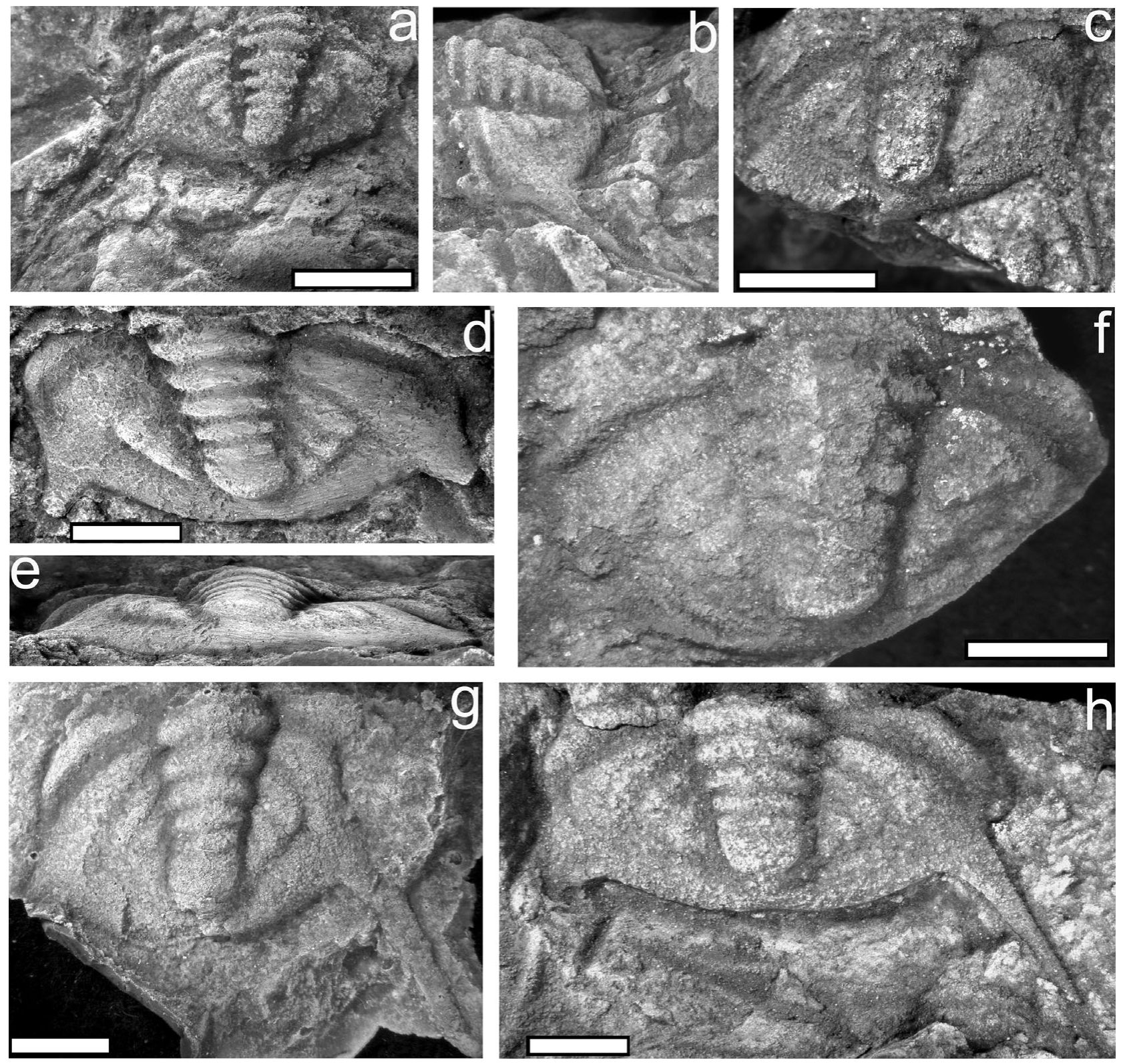

Figure 7. Pygidia of Kaolishania granulosa Kobayashi from the Quartzite Formation, Wachi La section, Bhutan. All specimens coated with ammonium chloride sublimate prior to digital photography, specimens are internal surfaces of moulds unless otherwise stated. White scale bar is $5 \mathrm{~mm}$ long. (a, b) GSB21; (a) dorsal view, (b) lateral-oblique view. (c) GSB22. (d, e) GSB23; (d) dorsal view, (e) posterior view. (f) GSB24. (g) GSB25, latex cast. (h) GSB26.

lengthening (sag.) medially. Ocular ridge oriented oblique rearward and outwards at about $20^{\circ}$ angle to transverse axis, originating approximately opposite anterior of S3. Palpebral lobe small, about $20 \%$ of glabellar length, elevated, with anterior opposite S2 and posterior opposite S1. Palpebral fixigenal width (tr.) $50 \%$ of glabellar width at palpebral area midlength. Preocular fixigenae widest opposite L3, truncated sharply by anterior border furrow. Posterior lateral border furrow firmly incised, lengthening (exsag.) abaxially. Preocular dorsal suture diverges slightly (exsag.) immediately anterior of palpebral lobe, then converges gently forward; postocular suture defines triangular posterior border.

Librigenal field slopes down into firmly incised lateral border furrow that is isolated from posterior border furrow by convex, ridge-like extension of librigenal field that extends from anterior portion of genal spine base. Lateral border inflated, rim-like. Posterior border short (exsag.), with firmly incised posterior border furrow that tapers into posterior of genal spine base. Genal spine broad (tr.) and straight sided, divergent from sagittal axis posteriorly, slightly less than length of the remainder of the librigena (exsag.).

Pygidium semi-elliptical with length (sag.) about $50 \%$ of maximum width (tr.), excluding spines. Axis tapers gently posteriorly with anterior width (tr.) about $30 \%$ of maximum pygidial width (tr.) and five firmly incised axial rings plus a bulbous terminal piece with possible additional ring furrow evident in some specimens. Articulating half ring short (sag.). Terminal piece longer (sag.) than anteriormost ring, with round posterior margin. Anterior band of anteriormost pleural segment short (exsag.), lengthening abaxially beyond distinct fulcrum. Anteriormost pleural furrow wide (tr.) and long (exsag.) with steep margins, long (exsag.) almost reaching pygidial margin. Posterior band of first pleural segment inflated abaxially, extending into long, posteriorly and abaxially directed, straight sided, marginal spines. In 
smaller specimens spine length (exsag.) roughly equal to pygidial width (tr.), and in larger specimens spine length is roughly equal to one half of pygidial width (tr.). Pleural field of subsequent segments crosses about half of pleural width, and traversed by four obliquely directed pleural furrows. Pleural field terminates at sharp, steep, break of slope separating pleural platform from flat border. Edge of pleural platform intersects terminal piece margin. Pygidial margin with slight emargination postaxially.

Discussion. Specimens from Wachi La have been subject to tectonic deformation, with specimens whose sagittal axis was at low angles to the principal extension direction becoming relatively elongated (Figs $6 \mathrm{a}, 7 \mathrm{~g}$ ), while those with sagittal axes at high angles to the principal extension direction have become tectonically shortened (Figs 6d, 7h). This deformation notwithstanding, species-specific characteristics are evident from this material. The reconstruction of the species (Fig. 12a) is based on a consideration of type and other nonBhutanese material assigned to the species, in addition to our new specimens.

Several specimens previously illustrated from the Wachi La belong to this species. One cranidium and one partial thoracopygon from the Wachi La section may belong to this species, but they are poorly illustrated and their assignment is uncertain (Chaturvedi, Mishra \& Mulay, 1983a,b, pl. 2, figs 1,3). Better-illustrated material that certainly belongs to this taxon has also been figured (Bhargava, 1995; Tangri \& Pande, 1995).

Kaolishania granulosa can be assigned to the genus with confidence, but other assignments are less secure. This is because either the material differs markedly from the forms of K. pustulosa and K. granulosa, or because the material is poorly preserved. The type material of Kaolishania granulosa is distinguished from Kaolishania pustulosa by its possession of larger pustules (Kobayashi, 1933, p. 104). While the holotype is poorly preserved, subsequent work by Kobayashi $(1935,1956,1960)$ expanded documentation of the species and added further illustrations, and our assignment of the Bhutanese material to $K$. granulosa is based on comparison with Kobayashi's additional material from North China and Korea.

The difference in pustule size of $K$. pustulosa and $K$. granulosa, while apparent in well-preserved material, is not a reliable character for species identification in all cases. The relatively coarse grain size of the Bhutanese specimens prohibits preservation of surficial ornament. Secondly, variation in pustule size or presence can be ontogenetic in some trilobites (e.g. Hughes, 1994). Other characters more useful for differentiating $K$. granulosa from $K$. pustulosa are the more semicircular pygidium of $K$. pustulosa with more firmly incised pleural furrows, which show five pleural ribs and six or seven axial rings in wellpreserved specimens with a terminal piece, whereas $K$. granulosa exhibits only four pleural ribs and five axial rings with an undivided terminal piece. The pygidial spines in $K$. pustulosa run sub-parallel to the axis, whereas the pygidial spines in $K$. granulosa are more strongly abaxially divergent posteriorly. Abaxial expansion of the posterior border furrow is more pronounced in K. granulosa than in K. pustulosa.

Kobayashi (1933, pl. 11, figs 15, 16) erected Kaolishania obsolata based on a fragmented cranidium and pygidium. Neither of these sclerites possesses characters diagnostic of Kaolishania, as both cranidium and pygidium are effaced, the cranidium has a narrow fixed cheek, and the pygidium bears only three axial rings. Kobayashi (1935, pl. 9, figs 1618) illustrated three additional fragmentary cranidia that he assigned to $K$. obsolata, but it is difficult to identify character states from the poor quality of the illustrations. The specimen figured as Kobayashi's (1935, pl. 9, fig. 16) is pustulated with a trapezoidal glabella with three furrows and an anterior border comparable to $K$. granulosa, whereas specimens in his plate 9 , figures 17 and 18 have weakly impressed furrows or lack them entirely, narrow fixigenae, and longer, more pointed anterior borders that differ from the condition in Kaolishania.

Kaolishania latiura (Kobayashi, 1960) was defined by a single pygidium that we consider similar to that of $K$. granulosa, and we treat $K$. latiura as a junior synonym of $K$. granulosa. Kobayashi (1960) assigned Teinistion sp. indet. Walcott (1913, pl. 9, fig. 4) to K. granulosa. Subsequently, Zhang \& Jell (1987) reassigned that specimen to Mansuyia without discussion of Kobayashi's (1960) reassignment. We concur that this specimen does not belong within Kaolishania due to the elliptical shape of the pygidium.

Resser (1942) distinguished the new species Kaolishania hopeiensis from a suite of specimens that Sun $(1935, \mathrm{pl}$. 2, figs 25-29) had assigned to K. pustulosa. The two cranidia that Sun (1935) figured do not show differences of likely taxonomic import, and the single pygidium illustrated shows as many as seven axial rings, five pleural ribs and rather weakly divergent pygidial spines, all of which suggest $K$. pustulosa. In our opinion the slight variation in cranidial length and pygidial width noted by Resser (1942) does not warrant recognition of a new species, especially when the small sample size is considered. Thus we concur with the opinion of Lu et al. (1965, p. 422) that Kaolishania hopeiensis is a synonym of $K$. pustulosa.

Zhang \& Wang (1985) established three new species, $K$. yanshanensis, $K$. pingquanensis and $K$. dongyushanensis, all from fragmentary material. Kaolishania pingquanensis was based on a single poorly preserved pygidium that might belong to one of several kaolishaniid genera. Kaolishania dongyushanensis was based on deformed material with a single cranidium weakly resembling Kaolishania. However, the pygidia figured contain eight axial rings plus a terminal piece, six pleural furrows and no preserved pygidial spines, all features that differ from other species of Kaolishania. Without clear evidence of pygidial spines we consider assignment to Kaolishania to be unconfirmed.

The pygidium of $K$. yanshanensis is nearly identical to that of $K$. pustulosa, whereas the figured cranidium (Zhang \& Wang, 1985, pl. 140, fig. 5) is similar to that in Kaolishania cylindrica, a species previously established by Guo \& Duan (1978). Duan et al. (2005) erected a new species also called Kaolishania yanshanensis that is broadly similar to K. yanshanensis Zhang \& Wang 1985, although the Duan et al. (2005) species is largely effaced with weakly incised glabellar furrows and large pustules. Kaolishania yanshanensis Duan is a junior homonym of $K$. yanshanensis Zhang \& Wang, but it is unclear whether it is also its junior synonym. All three of these species, $K$. cylindrica Guo \& Duan, K. yanshanensis Zhang \& Wang, K. yanshanensis Duan, have highly convex cranidia with short anterior borders and parallel-sided glabellae, and these features differ from the condition in typical Kaolishania. Both K. cylindrica and $K$. yanshanensis Duan also possess larger palpebral lobes than those of other Kaolishania species, and K. cylindrica contains particularly deeply incised bifurcate S1 glabellar furrows. All these features resemble Eokaolishania (Wittke, 1984; Zhu \& Wittke, 1989). Duan et al. (2005, p. 34) listed another new species, Kaolishania funingensis, in a stratigraphic column but provided no description or illustrations of this species, which is thus nomen nudum.

Kaolishania laevigata was erected based on a single quite poorly preserved pygidium that is kaolishaniid (Qian, 1994). 
It has only four axial rings, but we do not think that this single specimen warrants the recognition of a new species. Rather we restrict this name to this specimen pending the recovery of more material.

The species Kaolishania megaspina has been recognized from South China (Zhou et al. 1977) and was based on a single thoracopygon. This specimen differs from species of Kaolishania by having extremely long pygidial spines. Although the form of the pygidium is kaolishaniid, the lack of an associated cranidium precludes confident assignment of this species to Kaolishania.

Two other species have been described from western Yunnan by Sun \& Xiang (1979), and these are Kaolishania yunnanensis and Parakaolishania brevica, which was reassigned to Kaolishania by Shergold, Laurie \& Shergold (2007). Effacement of the glabellar furrows in $K$. yunnanensis and $K$. brevica distinguish these species from $K$. pustulos $a$ and $K$. granulosa, and in this respect they resemble the cranidia of Peichishania species, but both species are poorly known.

Shergold (1972) erected Kaolishania australis from the Gola Beds of western Queensland. Cranidia of this species differ from those of Kaolishania granulosa and K. pustulosa by possessing two pairs of isolated glabellar furrows and in having a very short anterior border. Shergold (1972, p. 51) acknowledged that the pygidia assigned to this species may not be correctly associated with the cranidia, and while the 'meraspid' pygidia figured (Shergold, 1972, pl. 21, figs 1, 3, 4) are generally similar to those of kaolishaniids except in the smaller number of axial rings, the single illustrated holaspid pygidium (Shergold, 1972, pl. 21, fig. 2) apparently has spines with a wider base than typical of other Kaolishania species. The cranidia of Kaolishania clarkensis Shergold, Laurie \& Shergold, 2007 from the Clark Sandstone of the Bonaparte Basin in NW Australia differ from the generic concept of Kaolishania by having a conical glabella with a rounded anterior end, a largely effaced cranidium with only faint $\mathrm{S} 1$, and a short, narrow anterior border. If it belongs within Kaolishania, it is quite different from the typical species $K$. pustulosa and $K$. granulosa.

In summary, two species K. pustulosa and K. granulosa can be assigned with confidence to the genus. Other putative members of the genus for which reasonably well-preserved material is available, such as $K$. clarkensis, $K$. australis and $K$. cylindrica, are distinctly different. Most other putative species are either likely synonyms of either K. pustulosa and K. granulosa or are too poorly know to be further evaluated.

Family TSINANIIDAE Kobayashi, 1935

Taipaikia has consistently been placed within this family of large, effaced trilobites (Kobayashi, 1960; Jell \& Adrain, 2003; Zhu, 2008). Although recent discussions have varied greatly in their assessment of tsinaniid affinities, we now consider the group to comprise large, effaced leiostegiinid trilobites with an extended preglabellar field (Zhu, Hughes $\&$ Peng, 2010). Fortey (1997) placed Tsinaniidae in Illaenina based on the presence of the lunettes, and this may be appropriate if the tsinaniid bacculae are indeed homologous with lunettes. Zhu, Hughes \& Peng (2007) noted that Taipaikia differed from other tsinaniids in the more abaxial position at which the facial suture intersects the anterior margin. In other respects Taipaikia closely resemble other tsinaniids.

Genus Taipaikia Kobayashi, 1960

1960 Taipaikia Kobayashi, p. 398.

1965 Taipaikia Kobayashi; Lu et al., p. 344.
1980 Taipaikia Kobayashi; Nan, p. 501.

2003 Taipaikia Kobayashi; Jell \& Adrain, p. 450.

2005 Taipaikia Kobayashi; Duan et al., p. 171.

2007 Taipaikia Kobayashi; Zhu, Hughes \& Peng, p. 248. 2008 Taipaikia Kobayashi; Zhu, pp. 140, 160, table 6.1.

Type species. Paramansuyella glabra Endo in Endo \& Resser, 1937, Changshan Formation, China.

Diagnosis. Effaced cranidium with long (sag.), concave frontal area with anterior branch of facial suture running abaxially anterior of the palpebral lobe, then sweeping adaxially in open curve to intersect anterior margin in front of fixigena. Glabellar conical with weakly incised anterior margin. Posterior border furrow and SO firmly incised. Posterior lateral margin of LO pit-like. Isopygous with convex, semicircular pygidium with distinct pleural facet, axis tapering posteriorly, border broad, flattened with broad doublure.

Taipaikia glabra (Endo in Endo \& Resser, 1937) Figures 8a-h, 9a-g, 10a-d, 12b

1937 Paramansuyella glabra Endo in Endo \& Resser, p. 358 , pl. 69, fig. 21, non 22 (=?Kaolishania).

1952 Mansuyia? glabra (Endo); Kobayashi, p. 148, pl. 20, fig. 18 .

1960 Taipaikia glabra (Endo); Kobayashi, p. 398, pl. 20, fig. 18, pl. 21, figs 20, 21.

1965 Taipaikia glabra (Endo); Lu et al., p. 344, pl. 64, fig. 14.

1980 Taipaikia glabra (Endo); Nan, p. 501, pl. 25, figs 5-8, 25.

?1995 Trilobite remains Tangri \& Pande, p. 134, fig. 3.10.6.

2005 Shergoldia yanshanensis Duan in Duan et al., p. 170, pl. 34, figs 12, 13.

2005 Taipaikia glabra (Endo); Duan et al., p. 171, pl. 34, figs 4-8, pl. 53, fig. 9.

2008 Taipaikia glabra (Endo); Zhu, p. 160.

Type material. Holotype cranidium Endo in Endo \& Resser, 1937, pl. 69, fig. 21, Changshan Formation, Kaolishania Zone, Paichiashan, Liaoning Province, China.

Bhutanese material. Five cranidia from WL-2 (GSB27, GSB28, GSB60, GSB62), WL-8 (GSB61); four librigena from WL-2 (GSB29, GSB31), WL-3 (GSB63), WL-8 (GSB30); and six pygidia from WL-2 (GSB33, GSB36) and WL-8 (GSB32, GSB34, GSB35, GSB37) from the Quartzite Formation, Wachi La section, Black Mountains, Bhutan.

Diagnosis. As for genus, monotypic.

Description. Effaced cranidium of moderate relief, length (sag.) about $75 \%$ of width (tr.) at posterior border. Glabella conical, low relief, tapering slightly and evenly anteriorly, about $75 \%$ of cranidial length (sag.). SO entire, firmly incised, shallowing abaxially but confluent with axial furrow and of even length (sag.), preoccipital glabellar furrows absent. Axial furrow moderately incised posteriorly, shallow anteriorly, preglabellar furrow absent, with anterior end of glabella sloping into concave frontal area. Posterior border furrow moderately well incised. Posterior of LO meets axial furrow in depressed, pit-like node. Ocular ridge straight, short (exsag.), extending from glabellar anterior lateral margin to the anterior of palpebral lobe at an angle of about $45^{\circ}$ to transverse axis. Palpebral lobe approximately $20 \%$ of cranidial length (sag.), oriented at about $30^{\circ}$ to sagittal axis with rearward divergence, posteriorly positioned 

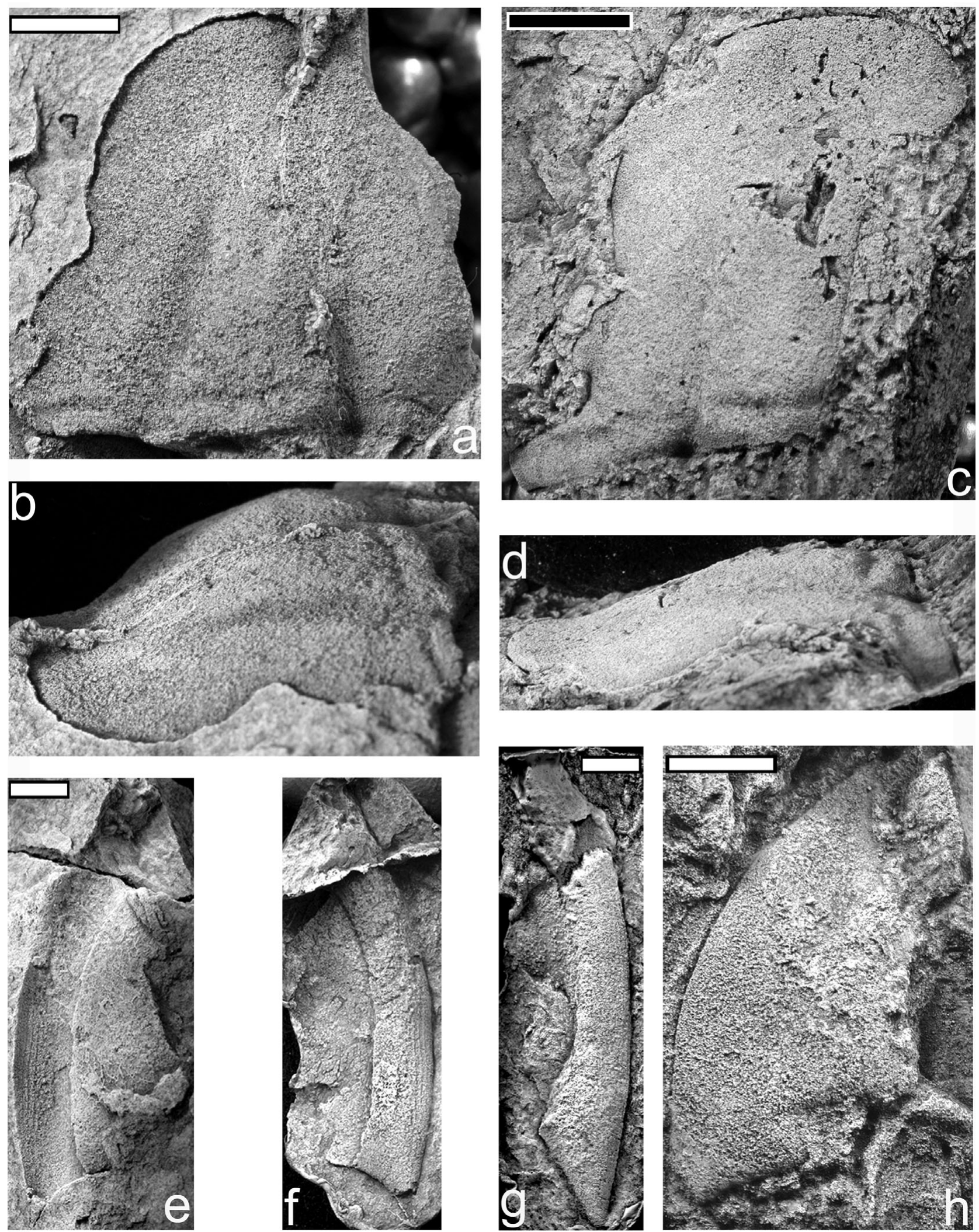

Figure 8. Cephalic sclerites of Taipaikia glabra (Endo) from the Quartzite Formation, Wachi La section, Bhutan. All specimens are coated with ammonium chloride sublimate prior to digital photography, specimens are internal surfaces of moulds unless otherwise stated. White scale bar is $5 \mathrm{~mm}$ long, black scale bar is $10 \mathrm{~mm}$ long. (a, b) GSB27, partial cranidium; (a) dorsal view; (b) oblique view. (c, d) GSB28, partial cranidium; (c) dorsal view; (d) lateral view. (e, f) GSB29, ventral doublure of librigena; (e) external mould; (f) latex cast. (g) GSB30, ventral doublure, latex cast. (h) GSB31, librigena. 

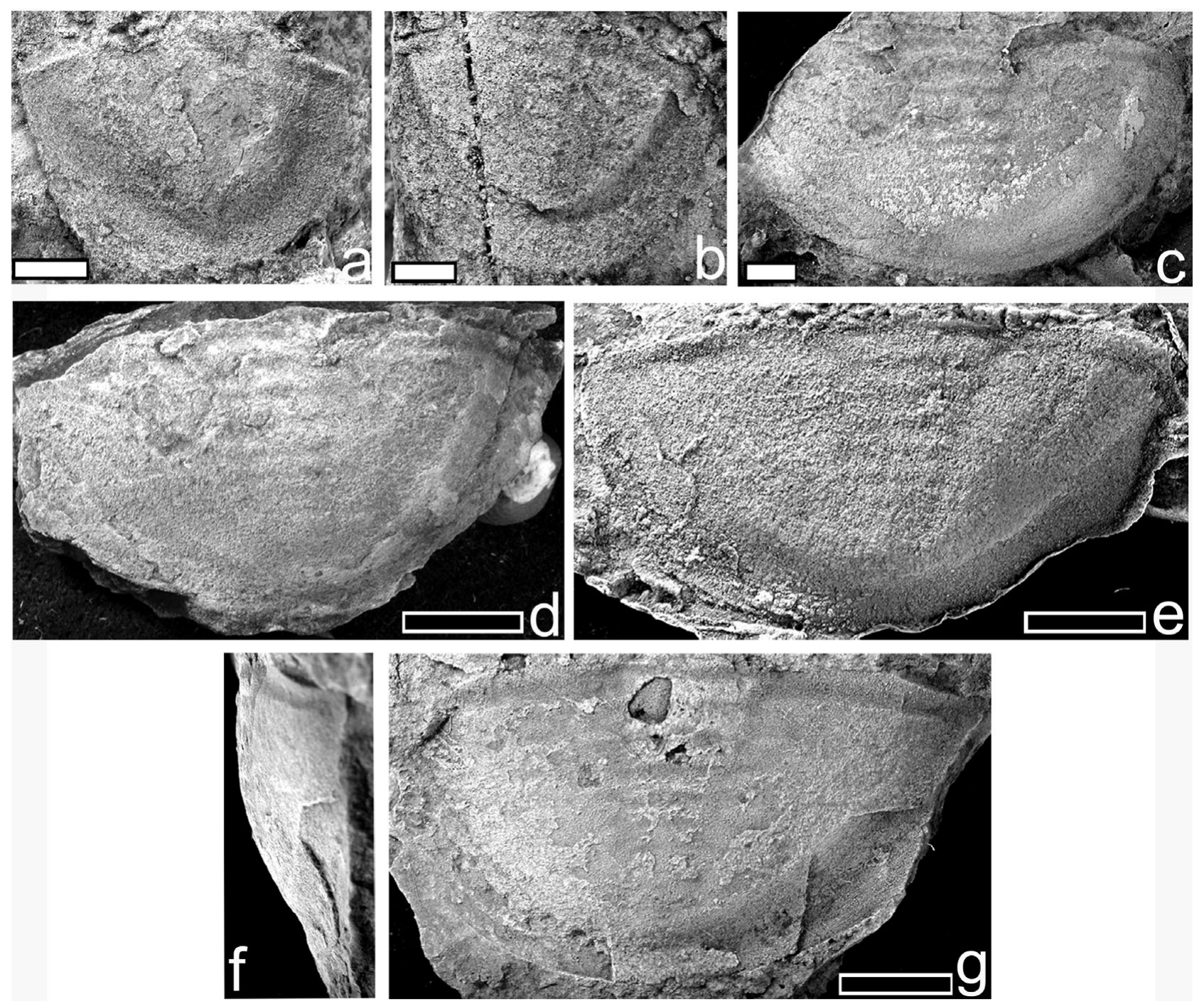

Figure 9. Pygidia of Taipaikia glabra (Endo) from the Quartzite Formation, Wachi La section, Bhutan. All specimens are coated with ammonium chloride sublimate prior to digital photography, specimens are internal surfaces of moulds unless otherwise stated. White scale bar is $5 \mathrm{~mm}$ long, black scale bar is $10 \mathrm{~mm}$ long. (a) GSB32. (b) GSB33. (c) GSB34, latex cast. (d) GSB35, (e) GSB36, latex cast. (f, g) GSB37; (f) lateral view; (g) dorsal view.

with anterior opposite glabellar midpoint. Palpebral furrow weakly incised. Interocular fixigenal width (tr.) equal to glabellar width (tr.) at palpebral area midlength. Prepalpebral fixigena about $80 \%$ of glabellar length at widest. Facial suture weakly divergent anterior to palpebral lobe, then curving gently and evenly toward anterior margin, which it intersects in front of fixigena. Posterior branch runs posteriorly for short distance behind palpebral lobe, then curves abruptly abaxially to define long, spatulate posterior border that obliquely truncates posterior border furrow. Posterior margin subtransverse adaxially, flexed posteriorly beyond weak fulcrum.

Librigenal border furrow effaced. Doublure wide, strongly convex ventrally, almost half of fixigenal width with prominent straight-crested terrace ridges on ventral surface at density of about 2 ridges $/ \mathrm{mm}$. Genal spine short (exsag.) and narrow (tr.), posteriorly directed. Librigenal length approximately twice width, suggesting cephalic width to length ratio of about $2: 1$.

Pygidium semicircular, of moderately high relief, sloping evenly and gently to posterior margin. Axis weakly inflated, straight-sided, decreasing in width (tr.) posteriorly, with up to 7 poorly defined axial rings in large specimens. Axis occupies about $75 \%$ of pygidial length (sag.). Articulating facet distinctly defined on abaxial portion of anterior border. Convex pleural platform slopes evenly into concave border, with slope inflection approximately coincident with weakly incised paradoublural line. Anteriormost pleural furrow evenly long (exsag.) and firmly incised, other pleural and interpleural furrows weakly incised near axis, effaced abaxially. Pygidial border broad, flat to slightly concave, extending across about one third of anterior pygidial width in small specimens and about one quarter of anterior pygidial width (tr.) in large specimens. Doublure with straight crested terrace lines approximately 3 ridges $/ \mathrm{mm}$, convex ventrally extending across about one third of pygidial width.

Discussion. The Bhutanese specimens assigned to this species have been tectonically deformed, and we have been able to retrodeform a cranidium that experienced simple oblique shear (see below). The pygidia show little oblique shear (Fig. 9), but it is notable that smaller specimens are relatively long and narrow (Fig. 9a, b) and larger pygidia relatively wide and short (Fig. 9c-g). These differences may result from deformation, in which the sagittal axes of the smaller specimens paralleled the principal extension 

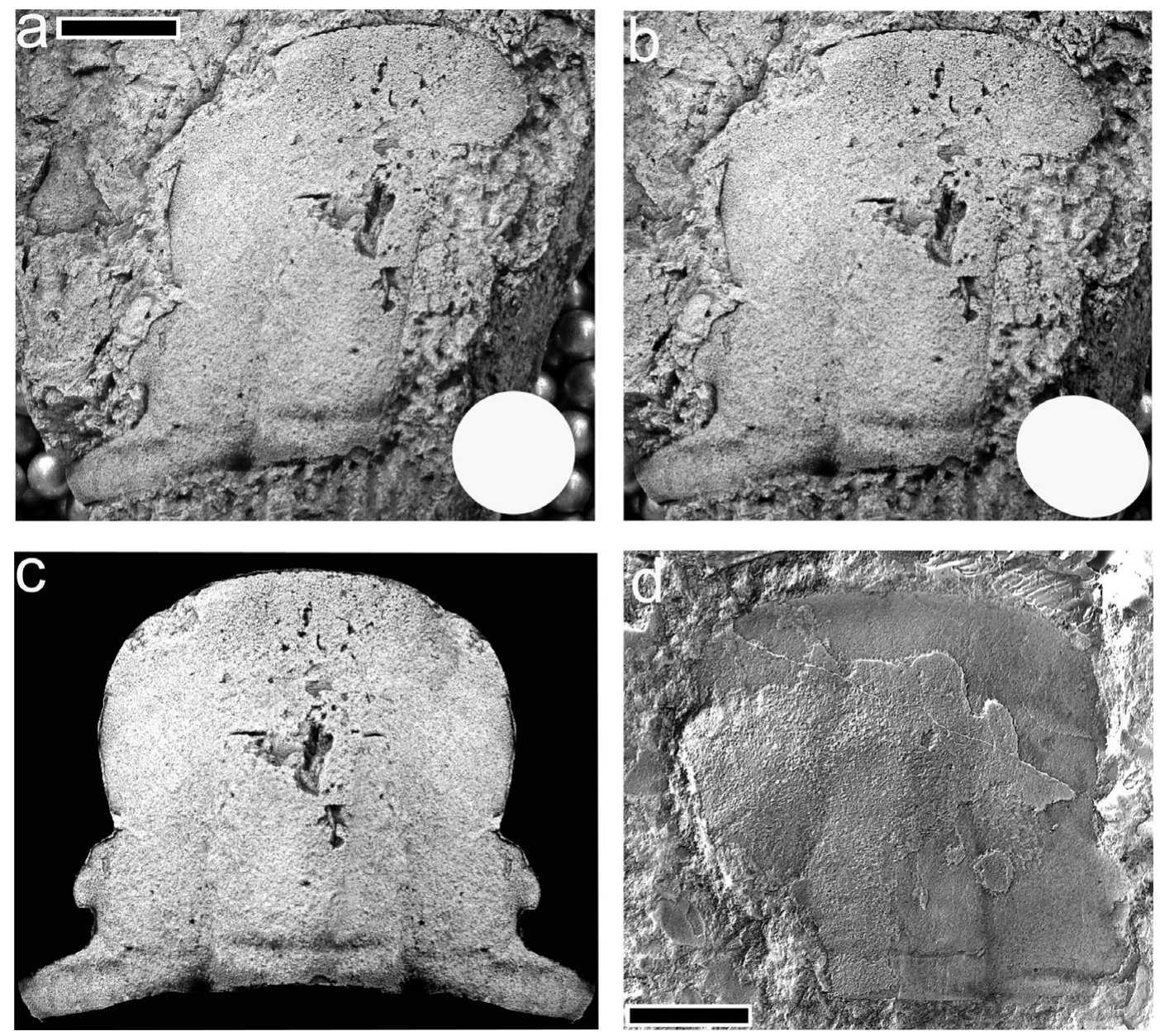

Figure 10. Comparison of retrodeformed Bhutanese specimen of Taipaikia glabra with Korean T. glabra. Black scale bar is $10 \mathrm{~mm}$ long. (a-c) GSB28 partial cranidium from the Quartzite Formation; (a) cranidium as recovered; (b) retrodeformation of (a) with strain ellipse (10\% pure shear); (c) composite image of single retrodeformed partial cranidium, reflected and digitally merged illustrating our concept of the form of the complete cranidium; (d) partial cranidium of $T$. glabra collected about $3 \mathrm{~km}$ northeast of the summit Mt Taebaek, Kaolishania zone, Taebaeksan Basin, Korea (counterpart of Kobayashi, 1960, p. 248, pl. 21, fig. 20) with pixels digitally inverted to create an image with positive relief, PA2481, University Museum, University of Tokyo.

direction, and those of the larger specimens were orthogonal to it. Further collecting will be needed to confirm whether this explanation or others, such as size-related shape change, are preferable.

Taipaikia glabra (Endo in Endo \& Resser, 1937) is known from various outcrops of the Changshan Formation in North China (Duan et al. 2005), and from a single locality in the Taebaeksan basin of South Korea (Kobayashi, 1960). Subtle differences exist between the Bhutanese and east Asian specimens of $T$. glabra. The Bhutanese specimens lack a well-defined medial ridge on a glabella that is slightly wider than in the type material, has a more spatulate posterior border of the cranidium, and bear one less distinctive ring on the pygidial axis. As these characteristics may reflect preservational differences between the tectonically deformed fine- to medium-grained siliciclastic material of Bhutan and the carbonate east Asian material, or minor intraspecific variation, we do not consider them to be of taxonomic significance.

The Bhutanese cranidia are fragmentary and tectonically deformed. As individual slabs preserve no more than a single cranidium or single pygidium of $T$. glabra, retrodeformation and reconstruction of a complete cranidium has been attempted (Fig. 10) by attempting to restore original approximate bilateral symmetry. The retrodeformation was achieved by compression of the digital image along the inferred principal extension direction and matching extension along axis orthogonal to principal extension (Hughes, 1999). The restoration of symmetry was judged using the outline of the anterior border. The portion of the specimen missing on the right hand side was copied, reflected and combined with the original image such that the anterior border was entire, thus creating an artificial image of a complete retrodeformed cranidium. This cranidium can be compared with the counterpart of an undeformed Korean specimen of this species preserved in limestone and figured by Kobayashi (1960, pl. 21, fig. 20). Digital inversion of the image of the unfigured original counterpart better illustrates features not preserved in the figured cast. The Korean specimen is similar to the retrodeformed Bhutanese specimen, notably in the shape of the anterior border, the location of the palpebral lobe, and proportion of the glabellar width and length relative to cranidial length and width. There is a slight difference in the depth and width of SO. The glabella in the Korean specimen is slightly more conical, although subtle variation is seen in this feature among other figured material preserved in limestone from a single locality (Duan et al. 2005, pl. 34, figs 4, 5). Accordingly, we do not consider that the Bhutanese material warrants a new species. 
Pygidia of T. glabra are similar to those of Shergoldia, but cranidia of Taipaikia are distinguished by small, more posteriorly situated palpebral lobes, and a more evenly rounded profile of the frontal area. In Shergoldia the facial suture cuts the anterior border in front of the glabella, defining a more pointed or 'spade'-shaped frontal area (e.g. Zhu, Hughes \& Peng, 2007, fig. 2F). Taipaikia also lacks the glabellar furrows seen in Shergoldia. Furthermore, no pygidia of Taipaikia have been found bearing the spines seen in pre-mature pygidia of Shergoldia (Zhu, Hughes \& Peng, 2007). Duan et al. (2005) erected the species Shergoldia yanshanensis based on material from a single locality from the Changshan Formation in Liaoning, North China, where the species co-occurs with Kaolishania granulosa and Lingyuanaspis lingyuanensis. The figures of the two pygidia of Shergoldia yanshanensis, one of which is holotype (Duan et al. 2005, pl. 34, figs 12, 13), are nearly identical to the pygidia of Taipaikia. Taipaikia appears to have been restricted the Kaolishania Zone which is stratigraphically below the base of the Ptychaspis-Tsinania Zone, in which other species of Shergoldia have been recovered.

\section{Order PTYCHOPARIIDA Swinnerton, 1915 \\ Family SOLENOPLEURIDAE Angelin, 1854}

Members of this 'ptychoparioid' family are grouped according to the possession of an inflated, sub-triangular glabella, and relatively narrow fixigena (Kobayashi, 1935). Lingyuanaspis was assigned to Solenopleuridae by Guo \& Duan (1978), an opinion maintained by Jell \& Adrain (2003) and Zhu (2008). We note that that Lingyuanaspis and Phylacterus are characterized by a similar sagittal preglabellar furrow that could denote shared ancestry, but until more is known we maintain Lingyuanaspis within Solenopleuridae.

\section{Genus Lingyuanaspis Guo \& Duan, 1978}

1978 Lingyuanaspis Guo \& Duan, p. 450.

2003 Lingyuanaspis Guo \& Duan; Jell \& Adrain, p. 398.

2005 Lingyuanaspis Guo \& Duan; Duan et al., pp. 27, 39.

2008 Lingyuanaspis Guo \& Duan; Zhu, pp. 140, 160, table 6.1

Type species. Lingyuanaspis lingyuanensis Guo \& Duan, 1978 (p. 450, pl. 2, figs 24-27) from the Changshan Formation, Laozhuanghu section, Lingyuan County, Liaoning Province, China.

Species assigned. In addition to the type species, Lingyuanaspis sangae sp. nov. is described herein.

Diagnosis. Cranidium of moderate to high relief, roughly triangular in outline, axial furrow deeply incised, inflated fixigena curve steeply into preglabellar field, meeting in depressed, anteriorly expanding (tr.) sagittal preglabellar furrow. Posterior margin of anterior border expanded posteriorly along sagittal axis. Pygidium trapezoidal, with deeply incised axial furrow and well-defined axial rings, and two short, posteriorly directed spines originating from pygidial margin just abaxial to axial furrow.

Discussion. This genus bears some resemblance to the middle Cambrian solenopleuriid genera Changqingia Lu \& Zhu in Qiu et al. 1983 and Eilura Resser \& Endo in Kobayashi 1935. We accept Austrosinia Zhang \& Jell, 1987 to be a junior synonym of Changqingia Lu \& Zhu in Qiu et al. 1983, as suggested by several authors (see Peng et al. 2009, p. 79). Zhang \& Jell (1987) acknowledged the similarity between Changqingia and Eilura, but noted differences in their pygidial outline and concavity. The cranidium of Lingyuanaspis is comparable to that of Changqingia in glabellar shape and the presence of a shallow sagittal preglabellar furrow, but the pygidium of Lingyuanaspis is more similar in outline to that of Eilura. Lingyuanaspis is distinguished from both these taxa by the presence of short posterior pygidial spines, a feature lacking in both Eilura and Changqingia.

Another comparable form is Phylacterus vermontanus (Raymond, 1937), which is known from Laurentian cranidia that are stratigraphically slightly above the level bearing Lingyuanaspis. The Laurentian species bore a comparable sagittal preglabellar furrow, but has wider fixigenae, a distinct ocular ridge (Ludvigsen, 1982, fig. 53A-D), and lacks marked posterior sagittal inflection of the anterior border. Phylacterus vermontanus also appears to be more strongly inflated than any Lingyuanaspis. Although the pygidium of $P$. vermontanus is unknown, the generic type species P. saylesi Raymond, 1924 has a triangular pygidium that contains multiple segments and is broadly comparable to that of Lingyuanaspis but differs in having more axial rings, an axis that extends almost of the posterior margin, and in lacking marginal spines (see Ludvigsen, Westrop \& Kindle, 1989, pl. 43).

\section{Lingyuanaspis sangae sp. nov. Figures $11 \mathrm{a}-\mathrm{p}, 12 \mathrm{c}$}

Name. In honour of Her Royal Highness Ashi Sangay Choden Wangchuck, Queen of Bhutan, in recognition of her interest in the natural and human heritage of her country, and for her efforts in its conservation.

Holotype. Cranidium (Fig. 11e, f), GSB5 from the WL-8 collection, Wachi La section, Quartzite Formation in the Black Mountain region, Bhutan.

Other material. Nine cranidia from WL-3 (GSB1, GSB2, GSB3, GSB4, GSB6, GSB7, GSB38), WL-5 (GSB39, GSB40); 10 pygidia from WL-2 (GSB11) WL-3 (GSB6, GSB7, GSB8, GSB9, GSB41, GSB42) and WL-5 (GSB10, GSB43, GSB44), Quartzite Formation, Wachi La section, Black Mountains, Bhutan.

Diagnosis. Lingyuanaspis with glabellar furrows absent or weakly incised. Pygidial pleural furrows absent or weakly incised.

Description. Cranidium of moderate relief with length (sag.) approximately $50 \%$ of width (tr.) at posterior border. Glabella conical, gently tapering and rounded anteriorly with preoccipital glabellar furrows absent or weakly incised, S1 pit-like, isolated where present. Occipital ring slightly narrower than glabellar width at posterior of L1, with firmly incised SO. Axial furrows deeply incised, preglabellar furrow slightly shallower. Preglabellar field short, about $15 \%$ of cranidial length (sag.) with prominent preglabellar furrow expanding anteriorly into broad (tr.) anterior border furrow. Anterior border narrow (tr.) with posterior margin slightly elongated sagittally. Anterior border about $15 \%$ of cranidial length. Palpebral lobe small, forward, inclined at $25^{\circ}$ angle to sagittal axis with anterior end adaxial, about $20 \%$ of cranidial length (sag.), interocular palpebral width $50 \%$ of glabellar width (tr.) at palpebral fixigenal midlength. Anterior branch of facial suture runs forwards and inwards. Posterior branch curves gently abaxially posterior to eye, then sweeps posteriorly. Posterior border slopes steeply into posterior border furrow in abaxial portion. Posterior border furrow long (exsag.), firmly incised.

Pygidium convex, length (sag.) about $60 \%$ of maximum width (tr.), trapezoidal in outline, width between abaxial 

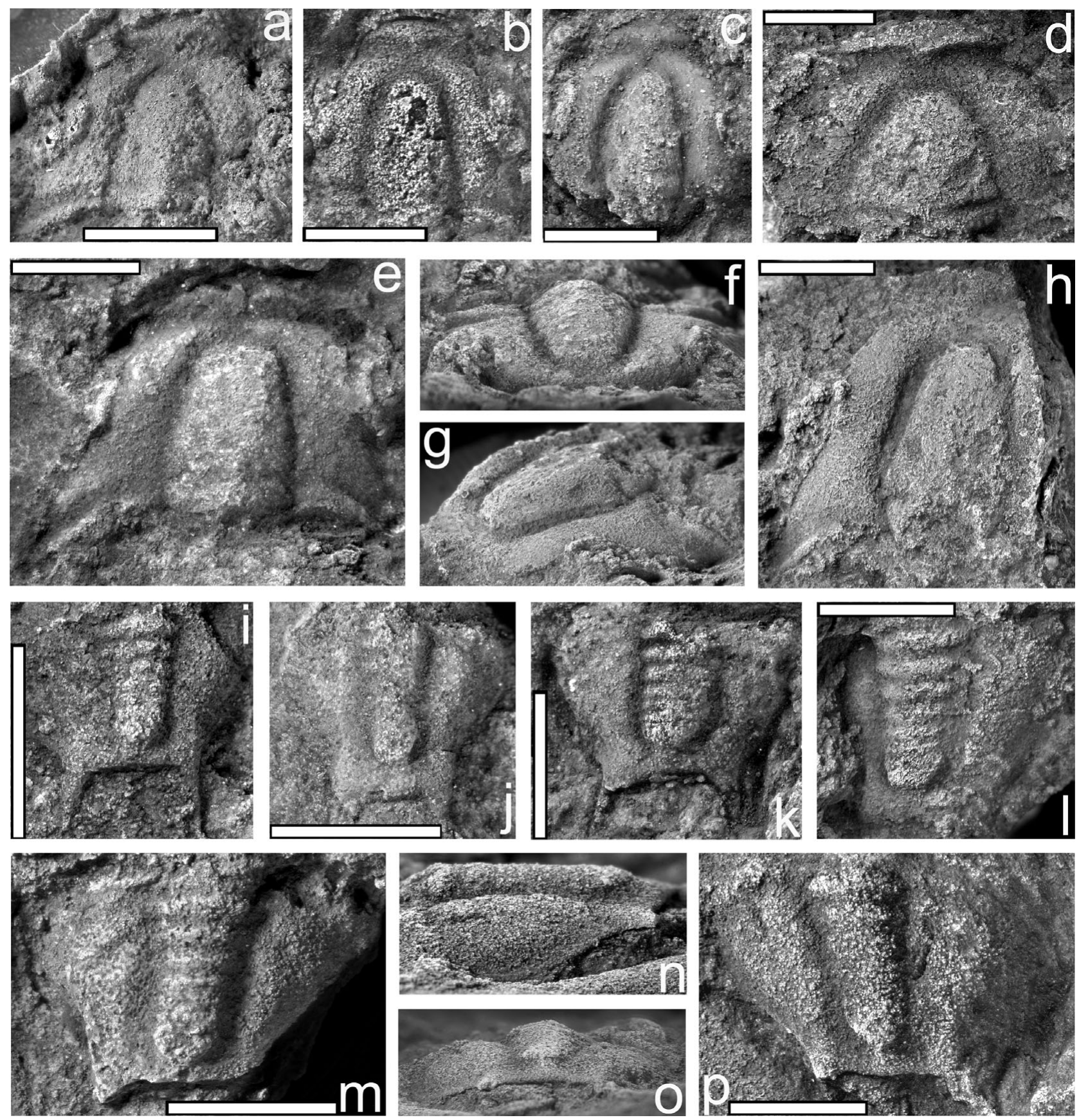

Figure 11. Lingyuanaspis sangae sp. nov. from the Quartzite Formation, Wachi La section, Bhutan. All specimens coated with ammonium chloride sublimate prior to digital photography, specimens are internal surfaces of moulds unless otherwise stated. White scale bar is $5 \mathrm{~mm}$ long in all figures. (a) GSB1, latex cast of partial cranidium. (b) GSB2, partial cranidium. (c) GSB3, partial cranidium. (d) GSB4, partial cranidium. (e, f) GSB5, cranidium, holotype; (e) dorsal view; (f) anterior view. (g, h) GSB38, partial cranidium; (g) oblique view; (h) dorsal view. (i) GSB6, partial pygidium. (j) GSB7, partial pygidium. (k) GSB8, pygidium. (1) GSB9, partial pygidium. (m) GSB10, partial pygidium. (n-p) GSB11, partial pygidium; (n) lateral view; (o) posterior view; (p) dorsal view.

pygidial spine base (tr.) $60 \%$ of maximum width (tr.). Posterior marginal spine pair straight sided, diverge abaxially at slight angle to sagittal axis. Spine base approximately $40 \%$ of anteriormost axial ring width (tr.). Spine up to approximately $40 \%$ of pygidial length. Posterior border between spines transverse or slightly emarginated sagittally. Axis occupies about $75 \%$ of pygidial length (sag.), strongly inflated, axial rings evenly decrease in width (tr.) posteriorly. Six or more axial rings plus terminal piece with bulbous, rounded end. Axial furrow firmly incised, axial ring furrows short (sag.), evenly incised, shallower posteriorly. Pleural field highly convex, sloping convexly downward from inflated pleural platform, effaced with one or rarely two furrows apparent anteriorly in some specimens.

Discussion. All specimens of $L$. sangae have experienced mild to moderate tectonic deformation. Those forms orthogonal to the axis of principal extension have become markedly shortened (Fig. 11d), while those parallel to that axis have been elongated (Fig. 11h). Accordingly, we have attempted a reconstruction (Fig. 12c) that approximates our view of the undeformed morphology.

The type species Lingyuanaspis lingyuanensis (Guo \& Duan, 1978) is only known from the Changshan Formation 


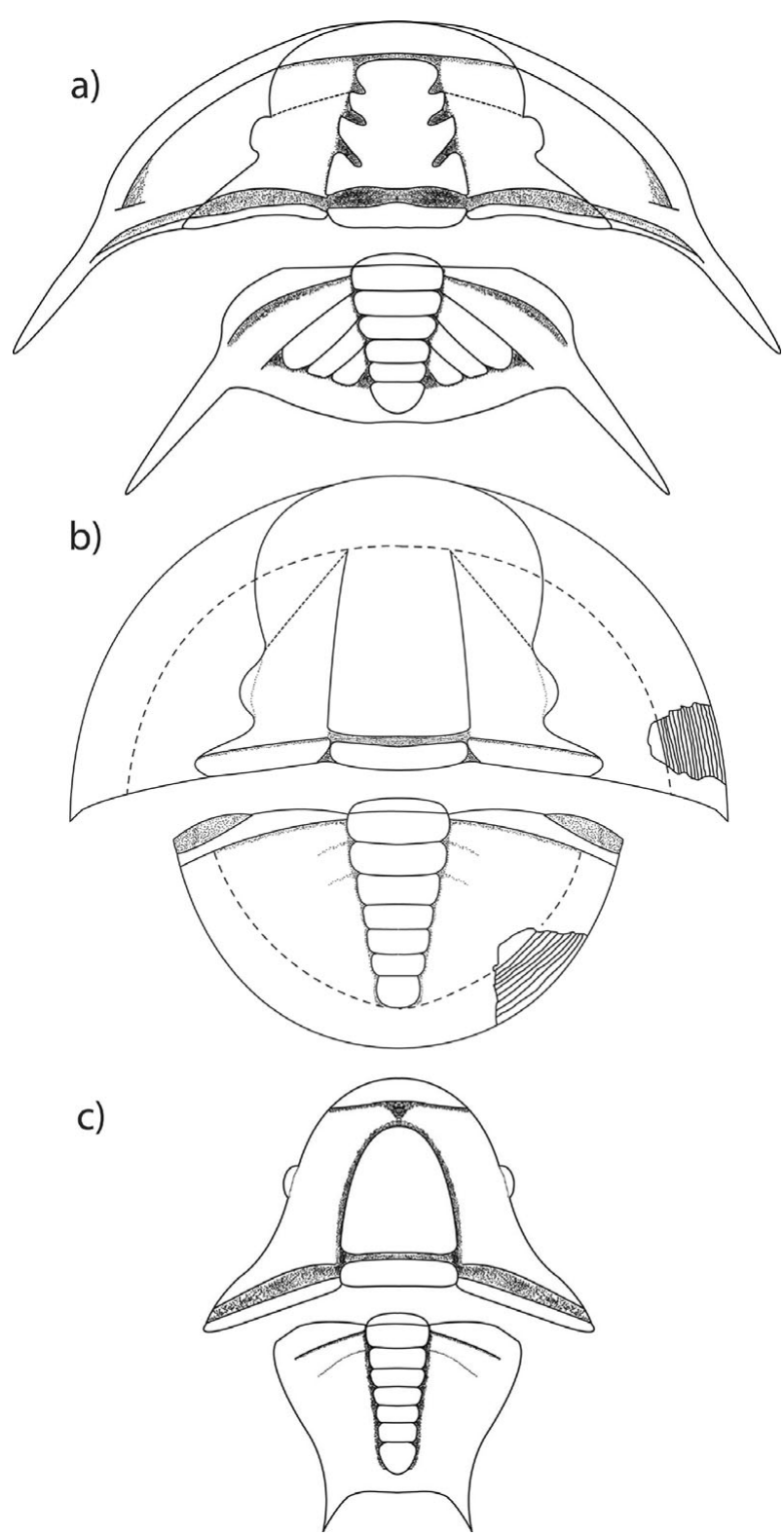

Figure 12. Schematic reconstructions of the Wachi La trilobite species. (a) Kaolishania granulosa; (b) Taipaikia glabra; (c) Lingyuanaspis sangae.

in the Laozhuanghu section in Lingyuan County and from the Yuanshishan section in Jinxi County of the Liaoning Province, North China (Duan et al. 2005). The presence of firmly incised lateral glabellar furrows distinguishes $L$. lingyuanensis from L. sangae. There is also a difference in glabellar shape, with the glabella of L. lingyuanensis tapering anteriorly to yield a more triangular form than that of $L$. sangae, which has a more gently tapered, conical glabella. The pygidia also differ with $L$. lingyuanensis displaying multiple well-defined pleural furrows, whereas the pleurae of $L$. sangae are effaced with no more than two faint furrows.

Phylum BRACHIOPODA

Class RHYNCHONELLIFORMA

Order BILLINGSELLIDA Schuchert, 1893

Suborder BILLINGSELLIDINA Schuchert, 1893

Superfamily BILLINGSELLOIDEA Schuchert, 1893

Family BILLINGSELLIDAE Schuchert, 1893
The billingsellids are a distinctive group of strophomenate brachiopods that have many features in common with the orthide brachiopods where until recently they were placed. Nevertheless, the presence of a pseudodeltidium and a chilidium together with transverse flat-lying socket plates and in particular a secondary shell layer consisting of crossbladed laminae, has required a reassignment of the group to the Strophomenida (Williams \& Harper, 2000). The family ranges from the middle Cambrian to the Lower Ordovician (Floian) and currently includes some six genera.

Genus Billingsella Hall \& Clarke, 1892

Type species. Orthis pepina Hall, 1863, p. 134, pl. 6, figs 23-27.

Billingsella is generally ventribiconvex with variable cardinal extremities, a strong pseudodeltidium and convex chilidium together with an apical foramen. The dental plates are widely divergent and the ventral muscle scars are commonly impressed on a long, tongue-like callus; a subperipheral rim is occasional developed. The other members of the family conform to the Billingsella model but have minor differences, mainly in overall shape and features of the ventral interior. Billingsella ranges from the middle Cambrian to the Lower Ordovician (Tremadocian) and has a cosmopolitan distribution. The majority of its some 20 reported species are known from the Furongian.

\section{Billingsella cf. tonkiniana Mansuy, 1915 Figure $13 \mathrm{a}-\mathrm{k}$}

cf. 1915 Billingsella tonkiniana Mansuy, p. 7, pl. I, fig. 2a-q.

cf. 1916 Billingsella tonkiniana Mansuy; Mansuy, p. 13, pl. I, fig. 12a-g.

$1983 a$ Rafinesquina sp. Chaturvedi, Mishra \& Mulay, pl. 1, figs 1-4, 6 .

$1983 a$ Orthis sp. ? Chaturvedi, Mishra \& Mulay, pl. 1, figs 5,7 .

$1983 a$ Chaturvedi, Mishra \& Mulay, pl. 1, figs 8, 9.

$1983 a$ Strophomenidae sp. Chaturvedi, Mishra \& Mulay, pl. 1, fig. 11.

?1983a ?Sowerbyites sp. Chaturvedi, Mishra \& Mulay, pl. 1, fig. 14.

1983 b Rafinesquina cratera Salter; Chaturvedi, Mishra \& Mulay, pl. 1, figs 1-4, 6 .

$1983 b$ Orthis cf. dalmenella Chaturvedi, Mishra \& Mulay, pl. 1, figs 5-7, 9.

$1983 b$ ?Strophomena sp. indet. Chaturvedi, Mishra \& Mulay, pl. 1, fig. 11

?1983b ?Sowerbyites sp. indet. Chaturvedi, Mishra \& Mulay, pl. 1, fig. 14.

1995 Brachiopod impression Tangri \& Pande, p. 134, fig. 3.10.41.

Material. Two dorsal conjoined exteriors and ventral interareas from WL-5 (GSB64, GSB69); one ventral exterior (GSB65) from WL-5 and one (GSB66) from WL-6; two dorsal interiors (GSB68, GSB70) from WL-5; one ventral interior (GSB67) from WL-5. The species also occurred in the following collections: WL-2, WL-7 and WL-8, Quartzite Formation, Wachi La section, Black Mountains, Bhutan.

Description. Exterior. Unequal, usually dorsibiconvex valves of transverse to subquadrate outline with maximum width commonly at or just anterior to hingeline; cardinal extremities rectangular or slightly obtuse. Anterior commissure slightly to markedly sulcate. Ventral valve feebly convex with low, flat median fold and planar to slightly concave 


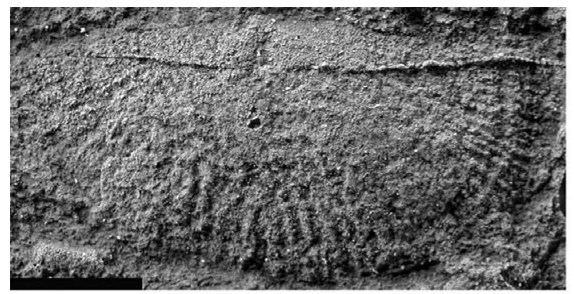

a

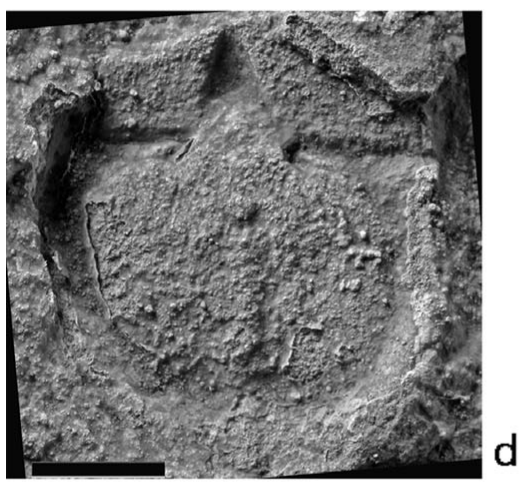

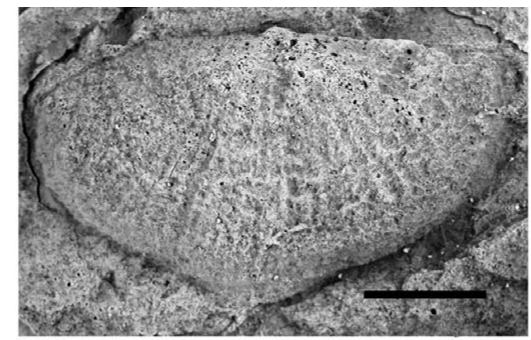

b

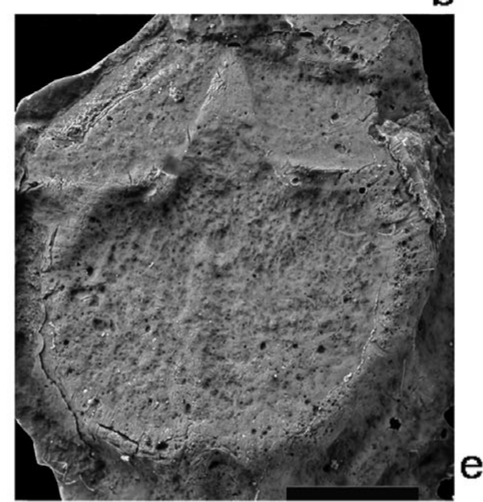

e
C

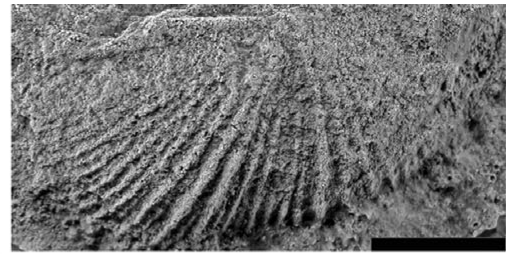

f

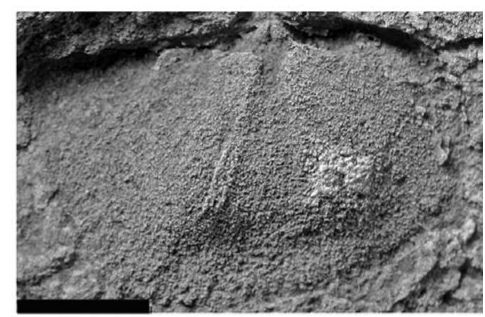

g

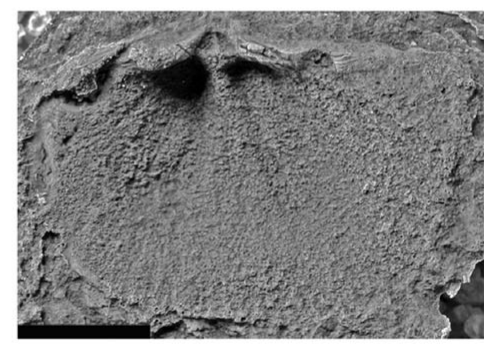

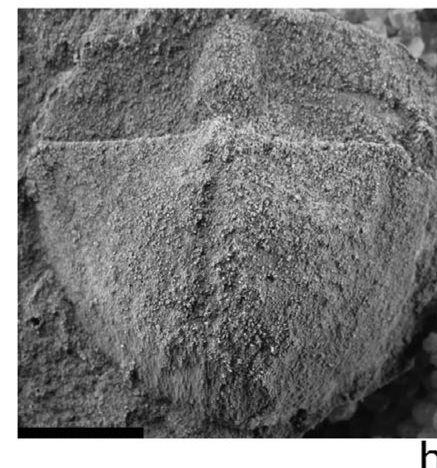

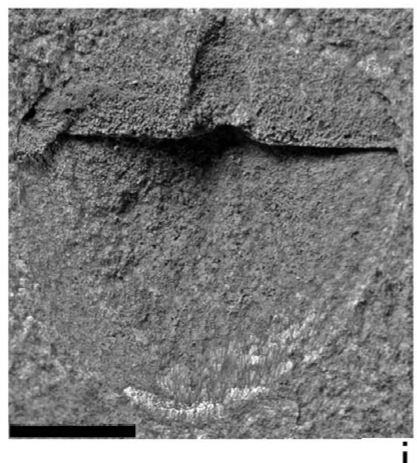

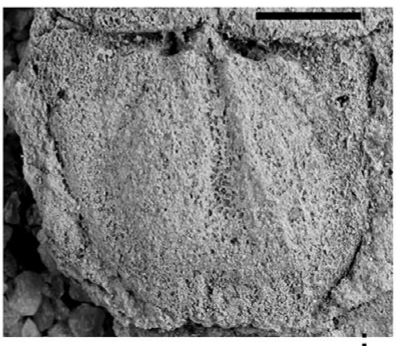

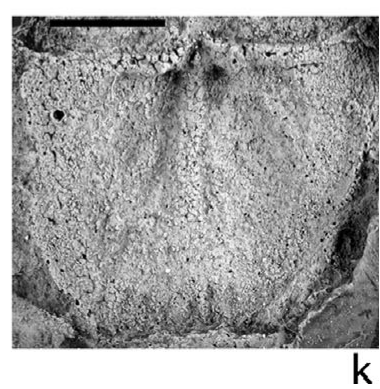

Figure 13. Billingsella $\mathrm{cf}$. tonkiniana Mansuy, 1915, from the Quartzite Formation, Wachi La section, Black Mountain outlier, Bhutan. (a) GSB64, latex replica of conjoined valves showing dorsal exterior and the ventral interarea. (b) GSB65, latex replica of ventral exterior; (c) GSB66, latex replica of dorsal exterior. (d, e) GSB67, internal mould of ventral valve and latex replica. (f, g) GSB68, internal mould of dorsal valve and latex replica. (h, i) GSB69, external mould and latex replica of conjoined pair showing dorsal exterior and ventral interarea. (j, k) GSB70, dorsal interior and latex replica of dorsal valve. Scale bar $5 \mathrm{~mm}$.

flanks. Ventral interarea high, flat with strongly convex pseudodeltidium, occupying about two-thirds of deltidium and with slight trace of minute, apical pedicle foramen. Dorsal valve convex with transverse outline; marked sulcus with steep sides arising at or near umbo, deepening and widening anteriorly; commonly flanked by two strong ribs and with curved base. Dorsal interarea relatively short, flat; chilidium relatively small, convex occupying the apical part of the notothyrium. Ornament of strong costae and costellae, with sharp profiles and flat interspaces; arising by both branching and intercalation; concentric growth lines variably developed, accentuated at and near anterior commissure; up to ten ribs developed per $5 \mathrm{~mm}$ at about $5 \mathrm{~mm}$ from dorsal umbo, with commonly five in the sulcus.

Ventral interior. Muscle scars not clearly discernible. Teeth, relatively large and robust, forming knoblike, divergent projections extending outwards from the anterolateral margins of the delthyrium.

Dorsal interior. Well-developed, high notothyrial platform with simple, bladelike cardinal process flanked by pair of suboval depressions, marking the site of the diductor scars; platform extended anteriorly as ridge, that broadens and fades within the posterior third of the valve length. Notothyrial platform flanked by flat-lying socket ridges that extend laterally, subparallel to hingeline, thickening slightly, distally. Posterior pair of adductor scars, oval, faintly impressed lateral to median ridge. Vascular media impressed and diverge anteriorly.

Discussion. This is a large, subquadrate to tranverse, dorsibiconvex Billingsella species with normally coarse costae and costellae, arising by branching and intercalation; the cardinal process is simple, situated on a high notothyrial platform with widely divergent socket ridges, subparallel to the hingeline; the large convex pseusodeltidium is perforated by minute apical foramen.

Several previous figured brachiopod specimens from the Quartzite Formation of the Wachi La section evidently belong to this species. Specimens assigned to Rafinesquina cratera are internal moulds of the ventral valve, whereas external moulds were generally assigned to Orthis cf. dalmenella (Chaturvedi, Mishra \& Mulay, 1983b). Our new material is also preserved as moulds and is variably deformed. The material exhibits a wide degree of morphological variation 
due partly to tectonic strain but in common with many other late Cambrian taxa, there is probably also a significant degree of biologically related morphological variation. Nevertheless, the biconvex, costellate shells with long interareas, and a large, convex pseudodeltidium perforated by an apical foramen and flat-lying socket ridges subparallel to the hingeline confirm an assignment to Billingsella. Approximately 20 species have been placed within Billingsella and many of those that have not already been reassigned to other genera, such as Oligomys and Wimanella, are in need of revision. Many species of Billingsella show wide variation in shell shape and ornament (Bell, 1941; Freeman $\&$ Stitt, 1996), and are thus difficult to characterize. The Bhutanese material is most similar to a group of species centred around B. perfecta Ulrich \& Cooper, 1938 but which also includes B. coloradoensis (Shumard, 1861) and B. texana Bell \& Ellinwood, 1962. This group has transverse dorsal and subquadrate ventral valves, a large pseudodeltidium and relatively coarse radial ornament. The Bhutanese species differs in having a high notothyrial platform, simple socket ridges developed virtually parallel to the hingeline and a lack of ridges in the dorsal interior, together with a raised muscle platform in the ventral valves.

A number of species of Billingsella have been reported from Shandong and Liaoning provinces of North China (Kobayashi, 1933; Endo \& Resser, 1937). Billingsella pumpellyi Walcott is reported and figured from the Furongian Changshan Formation of Shandong (Endo, 1939, pl. 1, fig. 9). The key characters of the species are its strongly convex ventral valve, a projecting ventral apex, a faintly-defined median fold and sharp, radiating ribs. Endo (1939), however, only figured a dorsal exterior. The Shandong material is apparently broken and poorly preserved, and although having sharp ribs and a sulcate anterior commissure, the Bhutanese material lacks a strongly-projected ventral apex, apparently typical of this form. Three new species were assigned by Endo \& Resser (1937) to Billingsella. Billingsella aojii is similar to $B$. pumpellyi but possesses less convex and wider valves. Billingsella simplex is characterized by a subcircular ventral valve, which is more convex and with finer ribs than the two latter species. Billingsella willisi, however, is subquadrate, moderately convex with fine ribs. All three are only briefly described and inadequately illustrated for comparison with the Bhutanese material.

Two new species were reported from the Liaoning Province (Kobayashi, 1933). Billingsella goettschei is similar to $B$. pumpellyi but is less convex and displays vascula media that are more narrowly divergent, whereas $B$. hsishunenesis is characterized by costellae that increase by intercalation and strong concentric growth lines. Both species are based on inadequate sample sizes and thus it is not possible to judge if these, and indeed the other species from China, are indeed recognizable species or merely part of a single, more variable species.

Mansuy $(1915,1916)$ described and illustrated two named species of Billingsella from Haut-Tonkin, which is part of the South China block. Billingsella loungeoensis Mansuy, 1916 is based on a transverse, ventral valve with a relatively fine ornament. It apparently lacks the high ventral interarea typical of Billingsella, and significantly Mansuy (1916) compared his species with Billingsella exporrecta Linnarsson, a Swedish species now assigned to Oligomys. Billingsella tonkiniana Mansuy, 1915 is adequately illustrated (Mansuy, 1915, 1916) and displays many of the features typical of Billingsella. Mansuy (1915) in fact compared his new species with B. coloradoensis (Shumard, 1861), and it is thus similar to both the American species and the new material described here (see above). The Haut-Tonkin material is similar in overall shape, particularly in the development of a dorsal sulcus and apparently has a similar density of ribbing. The Bhutan material has generally a more transverse outline and a higher ventral interarea; detailed comparisons with the interiors of Mansuy's species are not possible. Both species are tectonically deformed, making precise morphological comparisons difficult, but both are clearly similar. On this assumption and to avoid further proliferation of specific names, the Bhutanese material is compared with B. tonkiniana. Pending revision of Mansuy's species, the Bhutanese taxon may be included in that species, or its distinctive characteristics could form the basis for a new species.

The Billingsella Association (Bassett, Popov \& Holmer, 2002) was a low-diversity assemblage, dominated by the eponymous genus itself or closely related forms such as Cymbithyris. Many of these assemblages were limited in spatial distribution but formed high-density, high-dominance clusters in thin, locally extensive horizons commonly within nearshore facies. These distributional patterns suggest that Billingsella pursued an opportunist life strategy, forming thick near-monospecific shell beds in the middle and upper Cambrian rocks of Iran and the Furongian strata of northcentral Kazakhstan (Bassett, Popov \& Holmer, 2002). In the Wachi La section Billingsella occur throughout the fossiliferous interval and dominate some, but not all, beds in which they occur (Fig. 3).

\section{Age, biostratigraphy and biogeography of the Pele La Group}

\section{5.a. New stratigraphic constraints from the fossils described herein}

Our collections from the Quartzite Formation spanned about a $40 \mathrm{~m}$ stratigraphic interval, although the majority of the material is within $12 \mathrm{~m}$ of the base of this interval (Fig. 3). Individual beds contain different relative abundances, with the WL-5 and WL6 collections dominated by $B$. cf. tonkiniana, whereas the WL-2, WL-3 and WL-8 collections were trilobitedominated. As all three trilobite taxa occur throughout the section there is no indication of biozones within the section (Fig. 3).

The trilobite assemblage described here from the Quartzite Formation is unique, with all three of the Bhutanese trilobite genera known to be restricted to a narrow stratigraphic interval in North China (Sino-Korean block). Kaolishania granulosa occurs quite commonly in the Kaolishania pustulosa Zone of North China (the top zone of the Changshanian Stage in the traditional Chinese stage nomenclature), which is correlative to the Eolotagnostus decoratusKaolishaniella Zone of South China (Peng, 1992; Geyer \& Shergold, 2000; Choi \& Kim, 2006) (that is, within the lower portion of the Taoyuanian Stage in the slope-facies stages of China). It belongs to Stage 9 of the Furongian Epoch, and the age of this zone is estimated to be about $493 \mathrm{Ma}$ (Peng \& Babcock, 2008). This significantly modifies the middle Cambrian or Ordovician age estimate for the Quartzite Formation of the Pele La Group (Chaturvedi, Mishra \& Mulay, 1983a,b; Bhargava, 1995; Tangri 
\& Pande, 1995; Hughes, Peng \& Luo, 2002; Tangri, Bhargava \& Pande, 2003; Long \& McQuarrie, 2010). On the other hand, billingsellid brachiopod taxa have long stratigraphic ranges with the genus Billingsella extending from the middle Cambrian through the Early Ordovician (Tremadocian). The taxon also shows cosmopolitan distribution (Williams \& Harper, 2000). This, coupled with the lack of modern descriptions of many billingsellid taxa hinders their further use as biostratigraphic and biogeographic indicators.

The genus Kaolishania is well represented in North China by Kaolishania pustulosa and K. granulosa. Possible congeners also occur on the South China block (Yangtze platform), in Western Yunnan and in Australia, but those forms differ from the typical North Chinese species. The occurrence of $K$. granulosa in Bhutan thus suggests a specific link between Bhutan and North China. Furthermore, Taipaikia and Lingyuanspis are rare genera and are only known from North China. Taipaikia glabra has been collected from outcrops in the Changshan Formation in Liaoning, Hebei and Shandong provinces of North China (Duan et al. 2005) and the Sesong Formation of the Taebaeksan Basin in South Korea (Kobayashi, 1960). In both of these locations it co-occurs with Kaolishania granulosa (Endo \& Resser, 1937; Kobayashi, 1960; Duan et al. 2005). The only other species of Lingyuanaspis, L. lingyuanensis, is known only from a stratigraphically thin interval of the Changshan Formation at two localities in the Liaoning Province, North China, where it co-occurs with Taipaikia glabra and Kaolishania granulosa (Duan et al. 2005). Thus the co-occurrence of these three species in both Bhutan and North China allows both precise stratigraphic constraints to be placed on the age of the Bhutanese fauna, and a specific faunal association with North China to be advanced. These taxa have not been recovered from other areas bearing rock of similar age despite quite intensive studies of rocks of this age in South China and Australia.

In North China K. granulosa, T. glabra and Lingyuanaspis lingyuanensis occur in shallow water carbonate deposits as part of a mixed siliciclasticcarbonate succession (Duan et al. 2005; Kwon et al. 2006), whereas in Bhutan these taxa are found in nearshore, very fine- to medium-grained sandstone facies. Although both settings represent shallow shelfal conditions, the specific lithofacies were different, and occurrence of these taxa evidently was not exclusive to a single lithofacies. Hence there is no indication that this fauna occupied a particularly specialized physical habitat. Thus, proximity between North China and Bhutan, rather than specific environmental similarity, is a more likely explanation for the co-occurrence in both regions.

The Cambrian palaeogeographic position of India is well constrained as an element of core Gondwanaland (e.g. Scotese \& McKerrow, 1990; Veevers, 2000, 2004) and, assuming that the Cambrian Himalayan margin was continuous along strike and that Bhutan was part of it, as the stratigraphic and detrital zircon analyses suggest, this faunal association described herein would favour placement of the outboard North China block in relatively close proximity. This contrasts with other models in which North China is placed adjacent to eastern Australia or even further around the Gondwanan margin, adjacent to the Ross Sea margin of Antarctica (Huang et al. 2000; Li \& Powell, 2001).

Although the trilobite species allow specific stratigraphic and geographic correlation, the assemblage is of low diversity, as is quite common in Cambrian trilobite assemblages from nearshore sandstone facies. Sclerites of each of the three Bhutanese species have homeomorphs among co-occurrent trilobite species from other settings. For example, the pygidium of $K$. granulosa is grossly similar to that of species of Crepicephalus, the pygidium of $L$. sangae is similar to that of Uncaspis discrepans, and the overall size and form of both cranidia and pygidia of T. glabra resemble those of Coosia grandis from the Laurentian Crepicephalus Zone shale/limestone succession of central Montana (Lochman \& Duncan, 1944). This distantly related Laurentian fauna is significantly older, more diverse and from a different lithofacies than that of the Quartzite Formation. Nevertheless, similarity in aspects of the ecological structure of these disparate faunas is suggested by these resemblances.

\section{5.b. Implications for previous age estimates and correlations of the Pele La Group}

The fauna from the Quartzite Formation analysed in this paper suggest stratigraphic equivalence of the formation to members $\mathrm{G}$ and $\mathrm{H}$ of the Maneting Formation of Chaturvedi, Mishra \& Mulay $(1983 a, b)$ (Fig. 2). Those authors collected trilobites from several localities in their Member $\mathrm{H}$ of the Maneting Formation at Wachi La, and also in the Kha-Khola/Gongkhola area of the southern Black Mountains. On the basis of those fossils they considered the entire Maneting Formation to be Middle to Upper Ordovician, and the Deshichiling Formation (their Nake-Chu Formation) to be Lower Ordovician. Chaturvedi, Mishra \& Mulay's $(1983 a, b)$ figured specimens are difficult to identify from the photographs provided in their papers, and the original specimens have been lost. Several of the forms from the Wachi La section that they illustrate can be assigned to species we describe herein (see synonymies above). Other forms that they illustrated are likely different taxa. For example, their (Chaturvedi, Mishra \& Mulay, 1983a,b) plate 2, figures 10 and 11 might be a saukiid trilobite, a clade that we have not recovered in our own collections. Such a trilobite could have been collected from beds a little higher stratigraphically than those we collected. However, nothing illustrated from the Quartzite Formation in the Chaturvedi, Mishra \& Mulay $(1983 a, b)$ papers is suggestive of an Ordovician age.

Specimens illustrated by Tangri \& Pande (1995) and by Bhargava (1995) are from the WL-2 locality. 
Bhargava (1995, p. 178) suggested a middle to late Cambrian age for the Quartzite Member based on the specimens that these authors illustrated from WL-2, and based on the suggestion by J. H. Shergold that the trilobites were either kaolishaniids or pagodiids. On the basis of this identification Bhargava (1995) proposed a middle Cambrian age for this horizon. This was prompted by the supposedly earliest Cambrian age of the underlying Maneting Formation (Tangri, Bhargava \& Pande, 2003). Bhargava (1995) and Tangri, Bhargava \& Pande (2003) argued that the contrast between strata bearing simple trace fossils such as Planolites in the Deshichiling Formation and lowest parts of the Maneting Formation, and the occurrence of Treptichnus pedum (sensu Jensen, 1997) in the lower part of the Maneting Formation, suggested that this interval spanned the Precambrian-Cambrian boundary. However, none of the trace fossils illustrated by these authors are diagnostic of an early Cambrian age. Treptichnus pedum ranges from the base of the Cambrian into the Ordovician (Geyer \& Uchman, 1995), and rocks bearing this form are potentially of any age within that interval, although those on the Wachi La must be older than the trilobites described herein. Here we revise the age interpretation based on the new trilobite species identification, and this view is confirmed by the ages of detrital zircon grains from the Deshichiling Formation (see below). Our investigation shows that the leiostegiinid trilobite present is $K$. granulosa, not Prochuangia (see Hughes, Peng \& Luo, 2002). This taxonomic revision and the other species identifications suggest that the assemblage is younger than the age suggested previously by Hughes, Peng \& Luo (2002).

\section{Detrital zircon geochronology}

Two sandstone samples were taken from the Wachi La section for detrital zircon $\mathrm{U}-\mathrm{Pb}$ age analysis. WL-1 is from the upper part of the Deshichiling Formation at $\mathrm{N} 27^{\circ} 25.014^{\prime}$, E $090^{\circ} 16.609^{\prime}$, at $\sim 3942$ m altitude, and WL270.75 is from the WL-5 locality of the Quartzite Formation at a level from which $K$. granulosa, $L$. sangae and $B$. cf. tonkiniana were collected.

The detrital zircons were placed on mounts and polished, and then analysed using a sensitive highresolution ion microprobe (SHRIMP) at the Research School of Earth Sciences, Australian National University. Procedures used are those of Williams (1998). Photomicrographs were prepared for the grains using both reflected and transmitted light, as well as separate cathodoluminescence (CL) scanning electron microscope images. The latter were used to determine the internal structures of the grains, and to allow us to aim the $\sim 20 \mu \mathrm{m}$ diameter SHRIMP beam such that only the youngest single age component (the rims) was analysed within chosen grains. We initially analysed 60 grains for each sample (see online Appendix at http://journals.cambridge.org/geo), and then reanalysed the youngest grains (WL- $1 \mathrm{n}=5$; WL-

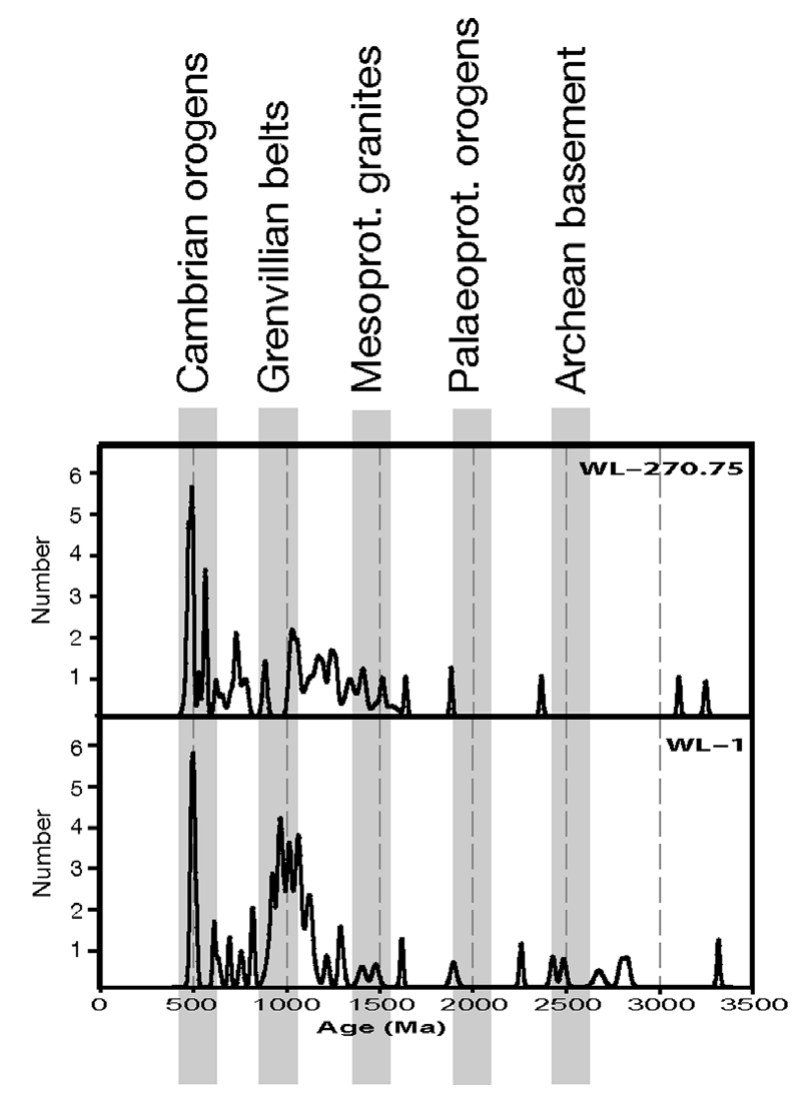

Figure 14. Detrital zircon age spectra from Cambrian and Ordovician strata from the WL-2 locality (WL-270.75), Quartzite Formation $(\mathrm{n}=54)$, and from the Deshichiling Formation $(\mathrm{WL}-1)(\mathrm{n}=56)$, Wachi La section, Bhutan.

$270.75 \mathrm{n}=4)$ for higher precision. The data were processed using the SQUID Excel macro of Ludwig (2001). U/Pb ratios were normalized relative to a value of 0.0668 for the Temora reference zircon, equivalent to an age of $417 \mathrm{Ma}$ (Black et al. 2003). Uncertainties given for individual analyses (ratios and ages) are at the one-sigma level (see online Appendix at http://journals.cambridge.org/geo). Correction for common $\mathrm{Pb}$ was either made using the measured ${ }^{204} \mathrm{~Pb} /{ }^{206} \mathrm{~Pb}$ ratio in the normal manner, or for grains younger than c. $800 \mathrm{Ma}$ (or those low in $\mathrm{U}$ and thus radiogenic $\mathrm{Pb}$ ) the ${ }^{207} \mathrm{~Pb}$ correction method was used (Williams, 1998). When the ${ }^{207} \mathrm{~Pb}$ correction is applied it is not possible to determine radiogenic ${ }^{207} \mathrm{~Pb} /{ }^{206} \mathrm{~Pb}$ ratios or ages. In general for grains younger than $c$. $800 \mathrm{Ma}$, the radiogenic ${ }^{206} \mathrm{~Pb} /{ }^{238} \mathrm{U}$ age was used for the relative probability plots; the ${ }^{206} \mathrm{~Pb} /{ }^{238} \mathrm{U}$ age is also used for grains that are notably low in $\mathrm{U}$, and therefore radiogenic $\mathrm{Pb}$. The ${ }^{207} \mathrm{~Pb} /{ }^{206} \mathrm{~Pb}$ age is used for grains older than c. $800 \mathrm{Ma}$, or for those enriched in U. For these older grains, those $>15 \%$ discordant have not been included in the relative probability plots.

The probability-density plot for sample WL-1 shows scattered Archaean, Palaeoproterozoic and Mesoproterozoic peaks (Fig. 14). Many of these peaks are found in rocks of roughly coeval depositional age from across the Himalaya (Myrow et al. 2010) and the Indian craton (Malone et al. 2008). A very large peak spans from approximately $800 \mathrm{Ma}$ to $1300 \mathrm{Ma}$, 
just as in other Himalayan samples. The rest of the profile consists of scattered prominent younger Neoproterozoic peaks and one large peak centered at about $500 \mathrm{Ma}$. The youngest grain in the sample is $489 \pm 8 \mathrm{Ma}$, and 13 grains have probable Cambrian age ranging up to $523 \pm 8 \mathrm{Ma}$. These data show that the Deshichiling Formation was almost certainly deposited in the late Cambrian, not earlier as was suggested by Tangri, Bhargava \& Pande (2003).

Sample WL-270.75 contains a broadly similar profile to that of WL-1. It contains two Archaean grains, scattered Palaeoproterozoic peaks, and a prominent cluster of latest Archean and Mesoproterozic peaks that span the interval from $1000 \mathrm{Ma}$ to $1700 \mathrm{Ma}$. Younger Neoproterozoic ages are abundant through $c .850 \mathrm{Ma}$, and include peaks at 600 and $750 \mathrm{Ma}$. There are nine grains with ages between 487 and $516 \pm 5 \mathrm{Ma}$. The youngest grain is $487 \pm 8 \mathrm{Ma}$. The depositional age of this sample is precisely constrained biostratigraphically by the trilobite fauna, which suggest a depositional age of about 493 Ma. Thus, as for early Palaeozoic samples in other parts of the Himalayan margin, the time lag between zircon crystallization in the magma and its deposition in the sediment was very short, on the order of a few million years or less.

The spectra from our samples are similar to each other, and to other spectra from Bhutan that are inferred to be of approximately similar depositional age (see samples NBH-18, NBH-5 of McQuarrie et al. 2008). This reflects the pattern common to all Cambrian samples from the Himalaya and cratonic India (Malone et al. 2008; Myrow et al. 2010). The common signature suggests a high degree of sediment mixing along the Himalayan margin (Myrow et al. 2010), and a wide variety of source material ages. The Archaean grains may have origins within India or in other parts of Gondwanaland (see Myrow et al. 2010). Palaeoproterozoic and Mesoproterozoic grains in our samples could have originated from a wide variety of sources within core Gondwanaland, but the prominent peaks of late Mesoproterozoic to early Neoproterozoic age, approximately 900 to $1300 \mathrm{Ma}$, were likely derived from orogenic belts produced by the assembly of Rodinia (Rivers, 1997; Fitzsimons, $2000 a, b)$. These 'Grenville'-age orogens surrounded the Indian continent within Gondwanaland and include provinces from east Antarctica (Boger et al. 2000; Harley \& Kelly, 2007), south-central Africa (Cahen et al. 1984) and Sri Lanka/south India (Fitzsimons, $2000 a, b)$. Local potential sources for grains of these ages include magmatic rocks in various tectonic units of Bhutan, Arunachal Pradesh and the Shillong plateau (Daniel et al. 2003; Richards et al. 2006; Chakungal et al. 2010; Yin et al. 2010a,b).

As with other Himalayan Cambrian detrital zircon spectra, we interpret the majority of Neoproterozoic grains to have been derived from the East African Mozambique orogenic belt (Squire et al. 2006; Yoshida \& Upreti, 2006; Cawood, Johnson \& Nemchin, 2007; Myrow et al. 2010). Events associated with this orogen took place between approximately 530 to $700 \mathrm{Ma}$. Gondwana assembly resulted in extensive organic systems (Cawood, Johnson \& Nemchin, 2007) with large-scale alluvial and fluvial depositional systems stretching across an unvegetated landscape, leading to extraordinary distances of sediment transport (Squire et al. 2006; Myrow et al. 2010). The $500 \mathrm{Ma}$ grains may have been locally derived in association with widespread granitic intrusion around the margin of Gondwanaland, including India (Debon et al. 1986; LeFort et al. 1986; Cawood, Johnson \& Nemchin, 2007).

McQuarrie et al. (2008) provided a detrital zircon spectrum from their sample BU07-1 from the 'Chekha Formation' collected from the Ura klippe to the east of the Wachi La. The spectrum is similar to those in our Wachi La samples, except that it lacks grains younger than approximately $800 \mathrm{Ma}$. Given that Himalayan sedimentary rocks of Cambrian age in nearly all cases include grains of approximately 500 to $650 \mathrm{Ma}$ age (Myrow et al. 2010), we suggest that the sample, collected near the base of the Chekha Formation, may be of Neoproterozoic depositional age. In contrast, recent work has suggested that Greater Himalayan rocks immediately beneath the Chekha Formation have ages as young as $460 \mathrm{Ma}$ (Long \& McQuarrie, 2010). These authors argue that the Chekha Formation unconformably overlies the Greater Himalaya, and that its age must be younger than $460 \mathrm{Ma}$. In the Wachi La area, rocks assigned to the Chekha Formation are thought to underlie the Pele La Group, here shown to be of Furongian age. A possible explanation of this significant anomaly is that rocks currently assigned to the Chekha Formation are of different depositional age in different regions. Additional stratigraphic constraints on the depositional age of the Chekha Formation are required.

Several samples collected in southern Bhutan, south of the Main Central Thrust from the Baxa Group and its lateral equivalents, also resemble our Wachi La spectra (McQuarrie et al. 2008, fig. 5). In particular, NBH-5 and NBH-18 bear similar profiles, except for a grain of about $300 \mathrm{Ma}$ age in sample NBH-18, which we consider likely to be unreliable. We concur with McQuarrie et al. (2008, p. 112) in interpreting these spectra to indicate depositional continuity between the Lesser Himalaya and Tethyan Himalayan parts of the Cambrian margin in Bhutan, supporting the continuous margin model of Myrow et al. (2003) and others. We also note that the proportion of Mesoproterozoic and Palaeoproterozoic grains is significantly higher in samples in which $500 \mathrm{Ma}$ grains are absent or uncommon (McQuarrie et al. 2008, fig. 5; Myrow et al. 2010). As Proterozoic grains are present in all samples of Cambrian rocks from the Himalaya, even those with many younger grains, we consider their reduced prominence in the younger samples to be the result of dilution.

We note that a sample from a trilobite-bearing interval from the Tal Group of India with a depositional 
age of c. 515 Ma lacks any grains younger than $625 \mathrm{Ma}$, but that a younger sample with a depositional age of $c$. $511 \mathrm{Ma}$ contains grains as young as $553 \mathrm{Ma}$ (Myrow et al. 2010). The interval between the deposition of these two samples could span the time of the earliest exhumation of the Cambrian Himalayan granites in the west-central Himalaya. Sedimentary rocks that lack grains of about 500 Ma were thus likely deposited more than $515 \mathrm{Ma}$ ago. McQuarrie et al.'s (2008) sample $\mathrm{NBH}-7$ lacks grains younger than about $850 \mathrm{Ma}$, and given the abundance of young Neoproterozoic grains in every published Cambrian sample in the Himalaya, was likely deposited significantly earlier in the Neoproterozoic. Hence we disagree with McQuarrie et al. (2008, p. 112) in viewing the age of the Baxa Group as entirely Cambrian or younger. Rather, we consider it likely that it represents a Neoproterozoic to Cambrian succession, as in the outer Lesser Himalaya of western central India. That aside, the lack of biostratigraphic data from the Baxa Group makes it difficult to correlate precisely this LH unit in Bhutan with any unit in the Chekha Formation, Pele La Group, or other units along strike in the Himalaya.

The ages of the youngest components of sample WL-1 indicate that the Deshichiling Formation is also Furongian (upper Cambrian). The striking abundance of 500 Ma grains in both the Deshichiling and Quartzite formations indicates that granitic intrusions associated with the Himalayan Kurgiakh (Srikantia, 1981) or Bhimphedian Orogeny (Cawood, Johnson \& Nemchin, 2007), part of the late assembly of Gondwanaland, were cooled, exhumed, and eroded shortly after their emplacement.

\section{Relationships with sedimentary successions in the Central and Western Himalaya}

The presence of post-early Cambrian and pre-Permian Palaeozoic rocks in Bhutan has been used to suggest similarity of the Wachi La regional stratigraphy with the Tethyan Himalaya in other parts of the Himalaya. In particular, correlations have been proposed with the Martoli and Garbyang formations of Kumaon (Nautiyal et al. 1964; Chaturvedi, Mishra \& Mulay, 1983b) and the Parahio Formation of Spiti (Bhargava, 1995). In fact, the trilobites and brachiopods described in this paper are not direct correlatives with deposits known anywhere else in the Himalaya, because the Bhutan strata are younger than any other Himalayan Cambrian strata. Our Wachi La collections are from Stage 9 of the Furongian Series (about 493 Ma old), whereas the youngest Cambrian faunas known elsewhere in the Himalaya are from the Proagnostus bulbus Zone of the Guzhangian Stage, and are thus about $501 \mathrm{Ma}$ old (Peng et al. 2009). Given that the Deshichiling Formation also contains zircon grains as young as $489 \pm 8 \mathrm{Ma}$, it is possible that the entire Bhutanese succession that we have studied is younger than the youngest Cambrian deposits recorded in Spiti. Our collections are also younger than the putative late
Cambrian trilobite fauna described from Kashmir (Jell, 1986) which, in our opinion, is also likely to be Guzhangian in age.

Lesser Himalayan sedimentary successions are distinguished from Tethyan Himalaya ones by the distinctive Permian unconformity (Brookfield, 1993), which cuts out all other post-Cambrian Palaeozoic rocks (see above). However, recent work on Himalayan Cambrian deposits has shown that at that time a continuous passive margin occupied the areas now represented by the Lesser Himalaya, Greater Himalaya and Tethyan Himalaya (Myrow et al. 2003, 2009, 2010; Hughes et al. 2005). Although some of the Bhutanese Cambrian rocks are younger than those known elsewhere in the Himalaya, the siliciclastic shelfal lithofacies of the Cambrian succession in Zanskar, Spiti, Kumaon and Qomolangma are broadly comparable to those in Bhutan, and the detrital zircon populations appear to be fundamentally similar. Hence Bhutan may have been part of the same passive margin sequence.

Relationships between the Pele La Group and the overlying Wachi La Formation on the Wachi La are uncertain due to incomplete exposure. However, tabulate corals recovered in the Wachi La limestone, above the fault at the top of our section (Fig. 5), suggest a late Ordovician/early Silurian age (Dr Bernard Hubmann, pers. comm. 2009). If this identification is confirmed, it significantly revises the inferred age of the Wachi La Formation, currently considered to be of late Palaeozoic age (Bhargava, 1995; Tangri \& Pande, 1995).

In the western-central Himalaya region, including the Kumaon, Spiti and Zanskar, Cambrian deposits are unconformably overlain by a thick coarse red conglomerate and sandstone succession that is probably Middle Ordovician or earlier in age (Torsvik et al. 2009). However, in Tibet, Cambrian deposits are in fault contact with Early Ordovician blue-weathering limestone (Myrow et al. 2009). Correlation of any of those rocks with the Bhutan sequence is presently unclear. It has been suggested that a polymictic conglomerate that reportedly underlies the Quartzite Formation near Kha-Khola of the Tongsa district in the southern Black Mountains (Gupta, 2004; Gupta \& Bandyopadhyay, 2009) correlates with the Thango conglomerate of India (Chaturvedi, Mishra \& Mulay, 1983b, p. 228). This horizon is also associated with copper sulphide mineralization in the adjacent Gongkhola-Nobji Chu region (Gupta, 2004; Gupta \& Bandyopadhyay, 2009). We have examined a prominent conglomerate above the town of Ura at N $27^{\circ} 29.565^{\prime}$, E $090^{\circ} 55.154^{\prime}$ at $3548 \mathrm{~m}$ altitude in the Ura klippe that has been specifically correlated with the Kha-Khola conglomerate (Chaturvedi, Mishra \& Mulay, 1983b, p. 227). It has characteristics significantly different from the Indian conglomerate. First, the clasts consist entirely of well-sorted and wellrounded cobbles of white, mature quartzite, which are surrounded by matrix of similar grain size and texture. The Ordovician conglomeratic deposits in northern 
India are poorly sorted, variably rounded and highly polymictic (Myrow et al. 2006b). Second, the cobbles of the Bhutan conglomerate are strongly deformed parallel to bedding. These cobbles are stretched so that originally spherical clasts presently have aspect ratios of 10:1. Confirmed Cambrian rocks in Bhutan are relatively unmetamorphosed in comparison with the marked deformation represented by these clasts. For these reasons, we consider this conglomerate may represent a different deformation (also see Tangri \& Pande, 1995).

In summary, important questions remain to be resolved concerning the correlation of Bhutanese Cambrian and Ordovician rocks with those along the Himalayan margin. With regard to the Wachi La section, no conglomerate is evident in Pele La Group, and no marked unconformity is indicated within the group or at the boundary with the Wachi La Formation. At Wachi La the boundary between the Quartzite Formation and the Wachi La Formation is a fault (see above).

\section{Relationships with sedimentary successions in other parts of Asia}

Himalayan Cambrian rocks described to date record parts of the first three series of the Cambrian System. This paper is the first record of Himalayan rocks of the fourth Cambrian series, the Furongian. Although older Cambrian faunas have been described from North and South China, Australia and Iran, such information is lacking for several significant tectonic units such as the Lhasa-Myanmar block, Sibumasu, Tarim and Indochina. These latter areas have deposits of Furongian age, as do both North and South China, and this permits a broader evaluation of the regional context of the Himalayan fauna.

Lithologically the Bhutanese fauna is part of a sandstone succession broadly comparable to that of the 'inner detrital belt' of Laurentia (Palmer, 1960). The lithology resembles that of trilobite collections made from the Northern Shan States of Myanmar (Myint, 1973), Tarutao Island in Thailand (Shergold et al. 1988) and the Baoshan region of western Yunnan (Sun \& Xiang, 1979; Luo, 1982, 1983, 1984, 1985). However, although the Bhutanese fauna is Asiatic and resembles that from the areas just listed in a general way, it shows specific affinity with that collected from a carbonate lithofacies in North China. Hence, while our faunal and detrital zircon analysis suggests that the Himalayan margin was contiguous with that of other areas of southeastern Asia during the late Cambrian, faunal evidence suggests particularly close linkage between Bhutan and North China.

\section{Conclusions}

The low-diversity trilobite fauna from the Quartzite Formation of the Pele La Goup at the Wachi La is representative of a late Cambrian Furongian (stage 9) age, approximately $493 \mathrm{Ma}$. This age is consistent with the ages of the youngest detrital zircon grains in a sample analysed from the trilobite-bearing beds. Similarity of the Bhutanese faunal assemblage to that of the North China block argues for geographic proximity between North China and north India during the Cambrian.

Detrital zircon spectra from the Pele La Group are similar to spectra from rocks of comparable age throughout the Himalaya, suggesting these strata where deposited in the same continuous margin as the rest of the Himalaya. The presence of $c .500 \mathrm{Ma}$ zircons in the upper part of the Deshichiling Formation provides a maximum age constraint of late Cambrian for the deposition of this unit. This is conformably overlain by the Maneting Formation, which is then conformably overlain by the Furongian Quartzite Formation. This result suggests that the stratigraphic interval from the upper part of the Deshichiling to the Quartzite Formation in the Wachi La section is all Furongian in age. Claims that the transition from the Deshichiling Formation to the Maneting Formation marks the Precambrian-Cambrian boundary are here rejected. The high concentration of $500 \mathrm{Ma}$ zircons in relatively young strata $(c .493 \mathrm{Ma})$ is a signature of the Cambro-Ordovician tectonic event seen throughout the Himalayan margin.

Acknowledgements. We thank Mr Dorji Wangda, Director of the Department of Geology and Mines of the Royal Government of Bhutan for permitting this work, and Mr Tobgay of the same institution for undertaking the organization. Funding was provided by National Geographic Society grant NGS7293-02 to N.C.H., with matching support from the National Science Foundation grant EAR-9980426 and EAR053868. P.M.M.'s contribution is supported by NSF EAR9980376 and EAR-054334. D.A.T.H. thanks the Carlsberg Foundation (Denmark) for support. Prof. Peng Shanchi and Dr Yuan Jinliang of the Nanjing Institute of Geology and Paleontology made helpful suggestions on the identifications and $\mathrm{Dr}$ Zhu Xuejian kindly provided translations. Dr Anupendu Gupta graciously provided information on the Gongkhola region. Prof. Peng, Dr Djordje Grujic and Dr Adrian Rushton each provided detailed reviews which greatly improved the paper. Ashmita Lahiri assisted with specimen preparation and preliminary identification, and Paul Hong helpfully discussed the North Chinese and South Korean trilobite fauna. Dr Sung-Bae Lee kindly provided images of Kobayashi's (1960) original material.

\section{References}

ANGELIN, N. P. 1851-1878. Crustacea Formations Transitionis, fasc. 1 (1851): Palaeontologia Suecica, pp. 124, pls 1-24; fasc. 2 (1854): Palaeontologia Scandinavica, pp. i-ix, 21-92, pls 25-41. In Palaeontologia Scandinavica, Pars 1. (Academiae Regiae Scientarum Suecanae: Holmiae) (ed. G. Lindström). Stockholm: Norstedt and Söner.

Bassett, M. G., Popov, L. E. \& Holmer, L. E. 2002. Brachiopods: Cambrian-Tremadoc precursors to Ordovician radiation events. In Palaeobiogeography and Biodiversity Change: The Ordovician and MesozoicCenozoic Radiations (eds J. A. Crame \& A. W. Owen), 
pp. 13-23. Geological Society of London, Special Publication no. 194.

BeLL, W. C. 1941. Cambrian Brachiopoda from Montana. Journal of Paleontology 15, 193-255.

Bell, W. C. \& EllinwoOD, H. L. 1962. Upper Franconian and lower Trempealeauan Cambrian trilobites and brachiopods, Central Texas. Journal of Paleontology 36, 385-423.

Bhargava, O. N. 1995. Correlation. In The Bhutan Himalaya: a geological account (ed. O. N. Bhargava), pp. 182-90. Calcutta: Geological Survey of India.

BHARGaVA, O. N. 1998. Geological account of the Tethyan rocks in the Spiti Valley: their comparison with Tethyan successions in other parts of the Himalaya. DehraDun: Wadia Institute of Himalayan Geology.

Black, L. P., Kamo, S. L., Allen, C. M., AleinikofF, J. N., DAVIS, D. W., Korscha, R. J. \& Foudoulis, C. 2003. TEMORA 1. A new zircon standard for Phanerozoic U-Pb geochronology. Chemical Geology 200, 155-70.

Boger, S. D., CARSON, C. J., Wilson, C. J. L. \& FANNING, C. M. 2000. Neoproterozoic deformation in the Radok Lake region of the northern Prince Charles Mountains, east Antarctica: evidence for a single protracted orogenic event. Precambrian Research 104, 1-24.

BRADLEY, J. H. 1925. Trilobites of Beekmantown in the Phillipsburg region of Quebec. Canadian Field Naturalist 39, 5-9.

BRENCHLEY, P. J. 1985. Storm influenced sandstone beds. Modern Geology 9, 369-96.

BRENNER, R. L. \& DAVIES, D. K. 1973. Storm-generated coquinoid sandstone: genesis of high-energy marine sediments from the Upper Jurassic of Wyoming and Montana. Geological Society of America Bulletin 84, 1685-98.

BROOKFIELD, M. E. 1993. The Himalayan passive margin from Precambrian to Cretaceous times. Sedimentary Geology 84, 1-35.

Cahen, L., Delhal, J., Vail, J. R., Bonhomme, M. \& LEDENT, D. 1984. The geochronology and evolution of equatorial Africa. Oxford: Clarenden.

CAwood, P. A., Johnson, M. R. W. \& Nemchin, A. A. 2007. Early Palaeozoic orogenesis along the Indian margin of Gondwana: tectonic response to Gondwana assembly. Earth and Planetary Science Letters 255, 70-84.

Chakungal, J., Dostal, J., Grujic, D., Duchêne, S. \& GHALlEY, K. S. 2010. Provenance of the Greater Himalayan sequence: evidence from mafic granulites and amphibolites in NW Bhutan. Tectonophysics 480, 198-212.

Chaturvedi, R. K., Mishra, S. N. \& Mulay, V. V. $1983 a$. On fossiliferous Ordovician rocks of Black Mountain region, Bhutan Himalaya and their significance in stratigraphic correlation. Records of the Geological Survey of India 113, 35-47.

Chaturvedi, R. K., Mishra, S. N. \& Mulay, V. V. $1983 b$. On the Tethyan Palaeozoic sequence of Black Mountain Region, Central Bhutan. Himalayan Geology 11, 224 49.

ChOI, D. K. \& KIM, E. Y. 2006. Occurrence of Changshania (Trilobita, Cambrian) in the Taebaeksan Basin, Korea and its stratigraphic and paleogeographic significance. Palaeogeography, Palaeoclimatology, Palaeoecology 242, 343-54.

Daniel, C. G., Hollister, L. S., Parrish, R. R. \& Grujic, D. 2003. Exhumation of the Main Central Thrust from lower crustal depths, eastern Bhutan Himalaya. Journal of Metamorphic Geology 21, 317-34.

Debon, F., LeFort, P., Sheppard, S. M. F. \& Sonet, J. 1986. The four plutonic belts of the Transhimalaya-
Himalaya: a chemical, mineralogical, isotopic, and chronological synthesis along a Tibet-Nepal section. Journal of Petrology 27, 219-50.

DiPietro, J. A. \& PogUe, K. R. 2004. Tectonostratigraphic subdivisions of the Himalaya: a view from the west. Tectonics 23, TC5001.

DOTT, R. H. JR \& BOURGEOIS, J. 1982. Hummocky stratification: significance of its variable bedding sequences. Geological Society of America Bulletin 93, 663-80.

DuAn, J., AN, S., LiU, P., Peng, X. \& Zhang, L. 2005. The Cambrian stratigraphy, fauna and palaeogeography in eastern of North China Plate. Hong Kong: Yayauan Publishing Company.

ENDO, R. 1939. Cambrian fossils from Shandung. In Jubilee Publication in Commemoration of Prof. H. Yabe's 60th Birthday (ed. R. Aoki), pp. 1-18. Sendai: Sasaki-Insatsu.

ENDO, R. \& RESSER, C. E. 1937. The Sinian and Cambrian Formations and fossils of southern Manchoukuo. Manchurian Science Museum Bulletin 1, 1-474.

FITZSIMONS, I. C. W. 2000a. A review of tectonic events in the East Antarctic Shield and their implications for Gondwana and earlier supercontinents. Journal of African Earth Sciences 31, 3-23.

FITZSIMONS, I. C. W. 2000b. Grenville-age basement provinces in East Antarctica: evidence for three separate collisional orogens. Geology 28, 879-82.

FORTEY, R. A. 1997. Classification. In Treatise on Invertebrate Paleontology, part O, Arthropoda 1. Trilobita, revised (ed. H. B. Whittington), pp. O289-302. Boulder and Lawrence: Geological Society of America and University of Kansas.

Freeman, R. J. \& StiTT, J. H. 1996. Upper Cambrian and lowest Ordovician articulate brachiopods from the Arbuckle and Wichita mountains, Oklahoma. Journal of Paleontology 70, 355-72.

GANSSER, A. 1983. Geology of the Bhutan Himalaya. Basel: Birkhäuser-Verlag.

Geyer, G. \& Shergold, J. H. 2000. The quest for internationally recognized divisions of Cambrian time. Episodes 23, 188-95.

GEYER, G. \& UCHMAN, A. 1995. Ichnofossil assemblages from the Nama Group (Neoproterozoic-Lower Cambrian) in Namibia and the Precambrian-Cambrian boundary problem revisited. In Morocco '95, The Lower-Middle Cambrian Standard of Western Gondwana (eds G. Geyer \& E. Landing), pp. 175-202. Beringeria Special Issue 2.

GolANI, P. R. 1995. Tethyan Sequence. In The Bhutan Himalaya: a geological account (ed. O. N. Bhargava), pp. 89-108. Calcutta: Geological Survey of India.

Grujic, D., Coutand, I., Bookhagen, B., Bonnet, S., Blythe, A. \& DunCan, C. 2006. Climatic forcing of erosion, landscape and tectonics in the Bhutan Himalayas. Geology 34, 801-4.

Grujic, D., Hollister, L. S. \& Parrish, R. P. 2002. Himalayan metamorphic sequence as an orogenic channel: insights from Bhutan. Earth and Planetary Science Letters 198, 177-91.

GuO, H. \& DuAN, J. 1978. Cambrian and Early Ordovician trilobites from northeastern Hebei and western Liaoning. Acta Palaeontologica Sinica 17, 445-62.

GuPTA, A. 2004. Palaeozoic metallogeny of the Tethyan Black Mountain Basin, Bhutan Himalaya and its regional implications. Himalayan Journal of Sciences 2, 150-1.

Gupta, A. \& Bandyopadhyay, B. K. 2009. Palaeozoic metallogeny in the Tethyan Black Mountain basin, Bhutan Himalaya, and its regional implications. Indian Journal of Geosciences 63, 97-106. 
HALL, J. 1863. Preliminary notice of the fauna of the Potsdam Sandstone. Sixteenth Annual Report of the Regents of the State of New York on the condition of the State Cabinet of Natural History, 119-226.

Hall, J. \& Clarke, J. M. 1892. An introduction to the study of the genera of Paleozoic Brachiopoda. New York Geological Survey 8, 1-367.

HAMBlin, A. \& WALKER, R. G. 1979. Storm-dominated shallow marine deposits: the Fernie-Kootenay (Jurassic) transition, southern Rocky Mountains. Canadian Journal of Earth Sciences 16, 1673-90.

HARLEY, S. L. \& Kelly, N. M. 2007. The impact of zircon-garnet REE distribution data on the interpretation of zircon $\mathrm{U}-\mathrm{Pb}$ ages in complex high-grade terrains: an example from the Rauer Islands, East Antarctica. Chemical Geology 241, 62-87.

HuAng, B., Zhu, R., OTOFuJI, Y. \& YANG, Z. 2000. The early Paleozoic paleogeography of the North China Block and the other major blocks of China. Chinese Science Bulletin 45, 1057-65.

HugHes, N. C. 1994. Ontogeny, intraspecific variation, and systematics of the Late Cambrian trilobite Dikelocephalus. Smithsonian Contributions to Paleobiology 79, 189.

HuGHES, N. C. 1999. Statistical and imaging methods applied to deformed fossils. In Numerical Palaeobiology (ed. D. A. T. Harper), pp. 127-55. London: John Wiley.

Hughes, N. C. \& Jell, P. A. 1999. The biostratigraphy and biogeography of Himalayan Cambrian trilobites. In Himalaya and Tibet: Mountain Roots to Mountain Tops (eds A. Macfarlane, R. B. Sorkhabi \& J. Quade), pp. 109-16. Boulder, Colorado: Geological Society of America, Special Paper no. 328.

Hughes, N. C., Peng, S.-C., Bhargava, O. N., Ahulwalia, A. D., Walia, S., Myrow, P. M. \& Parcha, S. K. 2005. The Cambrian biostratigraphy of the Tal Group, Lesser Himalaya, India, and early Tsanglangpuan (late early Cambrian) trilobites from the Nigali Dhar syncline. Geological Magazine 142, 57-80.

Hughes, N. C., Peng, S. \& LuO, H. 2002. Kunmingaspis (Trilobita) putatively from the Yunling Collage, and the Cambrian faunal history of the eastern Himalayan syntaxial region. Journal of Paleontology 76, 709-17.

JANGPANGI, B. S. 1978. Stratigraphy and structure of Bhutan Himalaya. In Tectonic Geology of the Himalaya (ed. P. S. Saklani), pp. 221-42. New Dehli: Today and Tomorrow Printers and Publishers.

JELL, P. A. 1986. An early Late Cambrian trilobite faunule from Kashmir. Geological Magazine 123, 487-92.

JELL, P. A. \& ADRAIN, J. M. 2003. Available generic names for trilobites. Memoirs of the Queensland Museum 48, 331-535.

JENSEN, S. R. 1997. Trace fossils from the Lower Cambrian Mickwitzia sandstone, south-central Sweden. Fossils and Strata 42, 1-111.

Kellett, D., GruJiC, D. \& ERDMAN, S. 2009. Miocene structural reorganization of the South Tibetan detachment, eastern Himalaya: implications for continental collision. Lithosphere 1, 259-81.

KIDWELL, S. M. 1991. The stratigraphy of shell concentrations. In Taphonomy - Releasing the data locked in the fossil record (eds P. A. Allison \& D. E. G. Briggs), pp. 211-90. New York: Plenum Press.

KoBAYASHI, T. 1933. Upper Cambrian of the Wuhutsui Basin, Liaotung, with special reference to the limit of the Chaumitien (or Upper Cambrian) of eastern Asia, and its subdivision. Japanese Journal of Geology and Geography 11, 55-155.
Kobayashi, T. 1935. The Cambro-Ordovician formations and faunas of South Chosen. Palaeontology. Part III. Cambrian faunas of South Chosen with a special study on the Cambrian trilobite genera and families. Journal of the Faculty of Science, Imperial University of Japan, Tokyo, Section II 4(2), 49-344.

KoBAYASHI, T. 1952. On Mansuyia and the Tsinanidae. Transactions and Proceedings of the Palaeontological Society of Japan New Series 5, 145-54.

KoBAYASHI, T. 1956. On the Kaolishaniinae. Japanese Journal of Geology and Geography 27, 9-20.

KoBAYASHI, T. 1960. The Cambro-Ordovician formations and faunas of South Korea, part VI, paleontology V. Journal of the Faculty of Sciences, University of Tokyo, Section 2 12(2), 217-75.

Komar, P. D. 1976. Beach Processes and Sedimentation. Englewood Cliffs, New Jersey: Prentice Hall.

Kwon, Y. K., Chough, S. K., Choi, D. K. \& Lee, D. J. 2006. Sequence stratigraphy of the Taebaek Group (Cambrian-Ordovician), mideast Korea. Sedimentary Geology 192, 19-55.

LeFort, P., Debon, F., PÊCher, A., Sonet, J. \& VidAl, P. 1986. The 500 Ma magmatic event in Alpine southern Asia, a thermal episode at Gondwana scale. Sciences de la Terre 47, 191-209.

LI, Z.-X. \& Powell, C. M. 2001. An outline of the palaeogeographic evolution of the Australasian region since the beginning of the Neoproterozoic. EarthScience Reviews 53, 237-77.

LOCHMAN, C. \& DunCAN, D. 1944. Early Upper Cambrian faunas from central Montana. Geological Society of America Special Papers 54, 1-181.

LONG, S. \& MCQUARRIE, N. 2010. Placing limits on channel flow: insights from the Bhutan Himalaya. Earth and Planetary Science Letters 290, 375-90.

Lu, Y., Chang, W., Chu, C. L., Chien, Y. Y. \& Hsiang, L. W. 1965. Chinese fossils of all groups, Trilobita, 2 volumes. Beijing: Science Press.

LUDVIGSEN, R. 1982. Upper Cambrian and Lower Ordovician trilobite biostratigraphy of the Rabbitkettle Formation, western District of Mackenzie. Royal Ontario Museum Life Sciences Contributions 134, 1-188.

Ludvigsen, R., Westrop, S. R. \& Kindle, C. H. 1989. Sunwaptan (Upper Cambrian) trilobites of the Cow Head Group, western Newfoundland, Canada. Palaoentographica Cadadiana 6, 1-175.

LUDWIG, K. R. 2001. SQUID 1.02, A User's Manual: Berkeley Geochronology Center Special Publication. No. 2. 2455 Ridge Road, Berkeley, CA 94709, USA.

LuO, H. 1982. On the occurrence of Late Cambrian Gushan trilobite fauna in western Yunnan. Contribution to the Geology of the Qinghai-Xizhang (Tibet) Plateau 10, 112.

LuO, H. 1983. New finds of trilobites from Late Cambrian in western Yunnan. Contribution to the Geology of the Qinghai-Xizhang (Tibet) Plateau 11, 1-30.

LuO, H. 1984. The discovery of the Late Cambrian Gushanaged strata in western Yunnan and their significance. Geological Review 30, 425-9.

LUO, H. 1985. Subdivision and correlation of the Cambrian system in western Yunnan. Yunnan Geology 4, 69-83.

Malone, S. J., Meert, J. G., BanerJee, D. M., Pandit, M. K., Tamrat, E., Kamenov, G. D., Pradhan, V. R. \& SoHL, L. E. 2008. Paleomagnetism and detrital zircon geochronology of the upper Vindhyan sequence, Son Valley and Rajasthan, India: a ca. 1000 Ma closure age for the Purana basins. Precambrian Research 164, 137-59. 
MansuY, H. 1915. Faunes Cambriennes du Haut-Tonkin. Mémoires du Service Géologique de l'Indochine 4, 135.

Mansuy, H. 1916. Faunes Cambriennes de l'ExtremeOrient méridional. Mémoires du Service Géologique de l'Indochine 5, 1-48.

MCQuARrie, N., RobinSON, D. M., LONG, S., TOBgAY, T., Grujic, D., Gehrels, G. \& DuceA, M. 2008. Preliminary stratigraphic and structural architecture of Bhutan: implications for the along strike architecture of the Himalayan system. Earth and Planetary Sciences Letters 272, 105-17.

MidTGAARD, H. 1996. Inner-Shelf to lower shoreface hummocky sandstone bodies with evidence for geostrophicinfluenced combined flow, Lower Cretaceous, West Greenland. Journal of Sedimentary Research 66, 34353.

MYINT, L. T. 1973. The Lower Paleozoic stratigraphy of western part of the Southern Shan State, Burma. Geological Society of Malaysia Bulletin 6, 143-63.

MYrow, P. M. 1998. Transgressive Stratigraphy and Depositional Framework of Cambrian Tidal Dune Deposits, Peerless Formation, Central Colorado, U.S.A. In Tidalites: Processes and Products (eds C. Alexander, R. A. Davis \& J. Henry), pp. 143-54. SEPM Special Publication no. 61.

Myrow, P. M., Hughes, N. C., Goodge, J. W., Fanning, C. M., Peng, S.-C., Bhargava, O. N., Tangri, S. K., Parcha, S. K. \& Pogue, K. R. 2010. Extraordinary transport and mixing of sediment across Himalayan central Gondwanaland during the CambrianOrdovician. Geological Society of America Bulletin 122, 1660-70.

Myrow, P. M., Hughes, N. C., Paulsen, T. S., Williams, I. S., PARChA, S. K., ThOMPSON, K. R., Bowring, S. A., Peng, S.-C. \& Ahluwalia, A. D. 2003. Integrated tectonostratigraphic reconstruction of the Himalaya and implications for its tectonic reconstruction. Earth and Planetary Science Letters 212, 433-41.

Myrow, P. M., Hughes, N. C., Searle, M. P., Fanning, C. M., PENG, S.-C. \& PARCHA, S. K. 2009. Stratigraphic correlation of Cambrian-Ordovician deposits along the Himalaya: implications for the age and nature of rocks in the Mt. Everest region. Geological Society of America Bulletin 120, 323-32.

Myrow, P. M., Snell, K. E., Hughes, N. C., Paulsen, T. S., Heim, N. A. \& PARChA, S. K. 2006a. Cambrian depositional history of the Zanskar Valley region of Indian Himalaya: tectonic implications. Journal of Sedimentary Research 76, 364-81.

Myrow, P. M. \& Southard, J. B. 1996. Tempestite deposition. Journal of Sedimentary Research 66, 87587.

Myrow, P. M., Thompson, K. R., Hughes, N. C., PAulsen, T. S., SEll, B. K. \& PARCha, S. K. 2006b. Cambrian stratigraphy and depositional history of the northern Indian Himalaya, Spiti Valley, north-central India. Geological Society of America Bulletin 118, 491510.

NAN, R. 1980. Trilobita. In Palaeontological Atlas of Northeast China, 1 (ed. Shenyang Institute of Geology and Mineral Resources), p. 731. Beijing: Geological Publishing House.

Nautiyal, S. P., Jangpangi, B. S., Singh, P., Sarkar, G. T. K., Bhate, V. D., RaghabVan, M. R. \& SAHAI, T. N. 1964. A preliminary note on the geology of Bhutan Himalaya. In Twenty Second International Geological Congress, pp. 1-14. India.
PAlmeR, A. R. 1960. Some aspects of the early Upper Cambrian stratigraphy of White Pine County, Nevada, and Vicinity. In Geology of East Central Nevada, pp. 53-8. Salt Lake City, Utah: Intermountain Association of Petroleum Geologists Guidebook 11th Annual Field Conference.

Pemberton, S. G. \& MAcEAchern, J. A. 1995. The sequence stratigraphic significance of trace fossils: examples from the Cretaceous foreland basin of Alberta, Canada. In Sequence Stratigraphy of Foreland Basin Deposits (eds J. C. Van Wagoner \& G. T. Bertram), pp. 429-75. Tulsa, Oklahoma: American Association of Petroleum Geologists Memoir no. 64.

PENG, S. 1992. Upper Cambrian biostratigraphy and trilobite faunas of the Cili-Taoyuan area, northwestern Hunan, China. Memoirs of the Association of Australasian Palaeontologists 13, 1-119.

Peng, S. \& BABCOCK, L. E. 2008. Cambrian Period. In The Concise Geological Timescale (eds J. G. Ogg, G. Ogg \& F. M. Gradstein), pp. 37-46. Cambridge: Cambridge University Press.

Peng, S., Hughes, N. C., Heim, N. A., Sell, B. K., Zhu, X., Myrow, P. M. \& PARChA, S. K. 2009. Cambrian trilobites from the Parahio and Zanskar Valleys, Indian Himalaya. Paleontological Society Memoirs 71, 1-95.

QIAN, Y. 1994. Trilobites from middle Upper Cambrian (Changshanian Stage) of North and Northeast China. Palaeontologia Sinica New Series B 30, 1-190.

QIU, H., LU, W., ZHU, Z., BI, D., LIN, T., ZHOU, Z., ZHANG, Q., QIAN, Y., JU, T., HAN, N. \& WIEI, X. 1983. Trilobita. In Paleontological Atlas of East China. Part 1: Early Paleozoic (ed. Nanjing Institute of Geology and Mineral Resources), pp. 28-254. Beijing: Geological Publishing House.

RAYMOND, P. E. 1924. New Upper Cambrian and Lower Ordovician trilobites from Vermont. Proceedings of the Boston Society of Natural History 37, 386-466.

RAYMOND, P. E. 1937. Upper Cambrian and Lower Ordovician Trilobita and Ostracoda from Vermont. Geological Society of America Bulletin 48, 1079-1146.

RESSER, C. E. 1942. Fifth contribution to the nomenclature of Cambrian fossils. Smithsonian Miscellaneous Collections 101, 1-58.

Richards, A., Parrish, R. R., Harris, N., Argles, T. \& ZHANG, L. 2006. Correlation of lithotectonic units across the eastern Himalaya, Bhutan. Geology 34, 3414.

RIVERS, T. 1997. Lithotectonic elements of the Grenville Province: review and tectonic implications. Precambrian Research 86, 117-54.

SCHUCHERT, C. 1893. A classification of the Brachiopoda. American Geologist 11, 141-67.

SCOTESE, C. R. \& MCKerRow, W. S. 1990. Revised world maps and introduction. In Palaeozoic Palaeogeography and Biogeography (eds W. S. McKerrow \& C. R. Scotese), pp. 1-21. Geological Society of London, Memoir no. 12.

SEARLE, M. P. 1996. Cooling history, erosion, exhumation, and kinematics of the Himalaya-Karakoram-Tibet orogenic belt. In Tectonics of Asia (eds A. Yin \& T. M. Harrison), pp. 110-37. Cambridge, England: Cambridge University Press (Rubey Volume).

SHERGOLD, J. H. 1972. Late Upper Cambrian trilobites from the Gola Beds, western Queensland. Bulletin of the Bureau of Resources, Geology and Geophysics Australia 112, 1-126.

Shergold, J. H., Burrett, C. F., Akerman, T. \& Stait, B. 1988. Late Cambrian trilobites from Tarutao Island, 
Thailand. New Mexico Bureau of Mines and Mineral Resources Memoir 44, 303-20.

Shergold, J. H., Laurie, J. R. \& Shergold, J. E. 2007. Cambrian and Early Ordovician trilobite taxonomy and biostratigraphy, Bonaparte Basin, Western Australia. Memoirs of the Association of Australasian Palaeontologists 34, 17-86.

SHUMARD, B. F. 1861. The primordial zone of Texas, with descriptions of new fossils. American Journal of Science and Arts 32, 213-21.

Squire, R. J., CAmpBell, I. H., Allen, C. M. \& Wilson, C. L. 2006. Did the Transgondwanan Supermountain trigger the explosive radiation of animals on Earth? Earth and Planetary Science Letters 250, 116-33.

SRIKANTIA, S. V. 1981. The lithostratigraphy, sedimentation and structure of Proterozoic-Phanerozoic formations of Spiti basin in the higher Himalaya of Himachal Pradesh, India. In Contemporary Geoscientific Researches in India (a commemorative volume in honour of S.P. Nautiyal) (eds A. K. Sinha \& S. P. Nautiyal), pp. 31-48. Dehra Dun: Bishen Singh Mahendra Pal Singh.

Sun, Y. \& XIANG, L. 1979. Late Upper Cambrian trilobite fauna from western Yunnan. Bulletin of the Chinese Academy of Geological Sciences 1, 1-17.

SuN, Y. C. 1924. Contributions to the Cambrian faunas of North China. Palaeontologia Sinica Series B 1, 1-109.

SuN, Y. C. 1935. The Upper Cambrian trilobite faunas of north China. Palaeontologia Sinica Series B 2, 1-69.

SWINNERTON, H. H. 1915. Suggestions for a revised classification of trilobites. Geological Magazine (New Series) 6, 487-96, 538-45.

TAngri, S. K., Bhargava, O. N. \& PAnde, A. C. 2003. Late Precambrian-Early Cambrian trace fossils from Tethyan Himalaya, Bhutan and their bearing on the PrecambrianCambrian boundary. Journal of the Geological Society of India 62, 708-16.

TANGRI, S. K. \& PANDE, A. C. 1995. Tethyan Sequence. In The Bhutan Himalaya: a geological account (ed. O. N. Bhargava), pp. 109-41. Calcutta: Geological Survey of India.

TERmier, G. \& GANSSER, A. 1974. Les séries dévoniennes du Tang Chu (Himalaya du Bhoutan). Eclogae Geologicae Helvetiae 67, 587-96.

TorsviK, T. H., Paulsen, T. S., Hughes, N. C., Myrow, P. M. \& GANERøD, M. 2009. The Tethyan Himalaya: paleogeographic and tectonic constraints from Ordovician paleomagnetic data. Journal of the Geological Society, London 166, 679-87.

Ulrich, E. O. \& COOPER, G. A. 1938. Ozarkian and Canadian Brachiopoda. Geological Society of America, Special Paper 13, 1-323.

VEEVERS, J. J. 2000. Billion-Year Earth History of Australia and Neighbours in Gondwanaland. Sydney: Gemoc Press.

VEEVERS, J. J. 2004. Gondwanaland from 650-500 Ma assembly through 320 Ma merger in Pangea to 185-100 Ma breakup; supercontinental tectonics via stratigraphy and radiometric dating. Earth-Science Reviews 68, 1132.

WALCOTT, C. D. 1913. The Cambrian faunas of China. In Research in China, Volume 3, pp. 3-276. Carnegie Institution Publication no. 54.

WALKER, R. G. 1984. Shelf and shallow marine sands. In Facies Models, Second Edition (ed. R. G. Walker), pp. 141-70. Geological Association of Canada.

Williams, A. \& HARPER, D. A. T. 2000. Billingsellida. In Brachiopoda. Volume 3: Linguilformea, Craniiformea, and Rhynchonelliformea (part) (eds A. Williams, C. H. C. Brunton \& S. J. Carlson), pp. H689-714. Boulder and Lawrence: Geological Society of America and University of Kansas.

WiLLIAMS, I. S. 1998. U-Th-Pb geochronology by ion microprobe. In Applications of Microanalytical Techniques to Understanding Mineralizing Processes (eds M. A. McKibben, W. C. Shanks \& W. I. Ridley), pp. 1-35. Reviews in Economic Geology 7. Littleton, CO: Society of Economic Geologists.

WitTKE, H. W. 1984. Middle and Upper Cambrian trilobites from Iran: their taxonomy, stratigraphy, and significance for provincialism. Palaeontographica, Abteilung A 183, 91-161.

YIN, A. 2006. Cenozoic tectonic evolution of the Himalayan orogen as constrained by along-strike variation in structural geometry, exhumation history, and foreland sedimentation. Earth-Science Reviews 76, 1-131.

Yin, A., Dubey, C. S., Kelty, T. K., Webb, A. A. G., HARRISON, T. M., CHOU, C. Y. \& CÉLÉRIER, J. $2010 a$. Geologic correlation of the Himalayan orogen and Indian craton: Part 2. Structural geology, geochronology, and tectonic evolution of the Eastern Himalayan. Geological Society of America Bulletin 122, 360-95.

Yin, A., DubeY, C. S., WebB, A. A. G., Kelty, T. K., Grove, M., GeHrels, G. E. \& BURGESS, W. P. 2010b. Geologic correlation of the Himalayan orogen and Indian craton: Part 1. Structural geology, U-Pb zircon geochronology, and tectonic evolution of the Shillong Plateau and its neighboring regions in NE India. Geological Society of America Bulletin 122, 336-59.

YoshidA, M. \& UPRETI, B. N. 2006. Neoproterozoic India within east Gondwana: constraints from recent geochronological data from Himalaya. Gondwana Research 10, 349-56.

Zhang, J. \& WANG, S. 1985. Trilobita. In Palaeontological Atlas of North China 1: Paleozoic Volume (ed. Tianjin Institute of Geology and Mineral Resources), pp. 1-332. Beijing: Geological Publishing House.

ZHANG, W. 1988. The Cambrian System in Eastern Asia, correlation chart and explanatory notes. Publication of the International Union of Geological Sciences 24, 181,4 charts.

ZhaNG, W. \& JeLL, P. A. 1987. Cambrian Trilobites of North China. Beijing: Science Press.

Zhou, T., LuI, Y., Meng, X. \& Sun, Z. 1977. Trilobita. In Palaeontological Atlas of South Central China (eds Geological Institute of Hubei, Geological Bureaus of Henan, Hubei, Guandong and Guanxi), pp. 104-226. Beijing: Geological Publishing House.

Zhu, X., Hughes, N. C. \& Peng, S. 2007. On a new species of Shergoldia Zhang and Jell, 1987 (Trilobita), the family Tsinaniidae and the order Asaphida. Memoirs of the Association of Australasian Palaeontologists 34, 243-53.

Zhu, X., Hughes, N. C. \& PENG, S. 2010. Ventral structure and phylogeny of the late Furongian (Cambrian) trilobite Guangxiaspis guangxiensis Zhou 1977 and the diphyletic origin of the median suture. Journal of Paleontology 84, 492-503.

ZHU, Z. 2008. Platform-facies non-agnostoids of Late Cambrian (Kushanian, Changshanian, and Fengshanian). In Trilobite Record of China (eds Z. Zhou \& Y. Zhen), pp. 136-61. Beijing: Science Press.

ZhU, Z. \& WiTTKe, H. W. 1989. Upper Cambrian trilobites from Tangshan, Hebei Province, North China. Palaeontologia Cathayana 4, 199-259. 